\title{
Galectin-3 as a novel biomarker for disease diagnosis and a target for therapy (Review)
}

\author{
RUI DONG ${ }^{1}$, MIN ZHANG $^{2}$, QUNYING HU ${ }^{2}$, SHAN ZHENG $^{1}$, ANDREW SOH $^{3}$, YIJIE ZHENG ${ }^{3}$ and HUI YUAN ${ }^{4}$ \\ ${ }^{1}$ Department of Pediatric Hepatobiliary Surgery, Children's Hospital of Fudan University and Key Laboratory of \\ Neonatal Disease, Ministry of Health, Shanghai 200433; ${ }^{2}$ Medical College, Xizang Minzu University, Xianyang, \\ Shaanxi 712000; ${ }^{3}$ Medical Scientific Affairs, Abbott Diagnostics Division, Abbott Laboratories, Shanghai 200032; \\ ${ }^{4}$ Department of Clinical Laboratory, Beijing Anzhen Hospital, Capital Medical University, Beijing 100029, P.R. China
}

Received June 5, 2017; Accepted November 29, 2017

DOI: $10.3892 /$ ijmm.2017.3311

\begin{abstract}
Galectin-3 is a member of the galectin family, which are $\beta$-galactoside-binding lectins with $\geq 1$ evolutionary conserved carbohydrate-recognition domain. It binds proteins in a carbohydrate-dependent and -independent manner. Galectin-3 is predominantly located in the cytoplasm; however, it shuttles into the nucleus and is secreted onto the cell surface and into biological fluids including serum and urine. It serves important functions in numerous biological activities including cell growth, apoptosis, pre-mRNA splicing, differentiation, transformation, angiogenesis, inflammation, fibrosis and host defense. Numerous previous studies have indicated that galectin-3 may be used as a diagnostic or prognostic biomarker
\end{abstract}

Correspondence to: Dr Hui Yuan, Department of Clinical Laboratory, Beijing Anzhen Hospital, Capital Medical University, 2 Anzhen Road, Beijing 100029, P.R. China

E-mail: 18911662931@189.cn

Dr Yijie Zheng, Medical Scientific Affairs, Abbott Diagnostics Division, Abbott Laboratories, Ciro's Plaza, 388 Nanjing West Road, Shanghai 200032, P.R. China

E-mail: yijie.zheng@abbott.com

Abbreviations: CRD, carbohydrate-recognition domain; HF, heart failure; eGFR, estimated glomerular filtration rate; LVEF, left ventricular ejection fraction; NT-proBNP, N-terminal pro-B-type natriuretic peptide; $\mathrm{HFpEF}$, HF patients with a preserved ejection fraction; HFrEF, HF patients with a reduced ejection fraction; LVAD, left ventricular assist device; LV, left ventricular; sST2, soluble suppression of tumorigenicity 2; BNP, B-type natriuretic peptide; CHD, coronary heart disease; MI, myocardial infarction; AF, atrial fibrillation; STEMI, ST-elevated myocardial infarction; pPCI, primary percutaneous coronary intervention; IL, interleukin; $\mathrm{HT}$, heart transplantation; ARF, acute renal failure; CKD, chronic kidney disease; HD, hemodialysis; RCC, renal cell carcinoma; PTC, papillary thyroid carcinoma; HBME-1, Hector Battifora mesothelial epitope-1; HCC, hepatocellular carcinoma; NASH, non-alcoholic steatohepatitis

Key words: galectin-3, tumor biomarker, heart disease for certain types of heart disease, kidney disease and cancer. With emerging evidence to support the function and application of galectin-3, the current review aims to summarize the latest literature regarding the biomarker characteristics and potential therapeutic application of galectin-3 in associated diseases.

\section{Contents}

1. Introduction

2. Galectin-3 and cardiovascular disease

3. Galectin-3 and renal disease

4. Galectin-3 and cancer

5. Galectin-3 as a therapeutic target

6. Conclusion

\section{Introduction}

Galectins are a family of $\beta$-galactoside-binding lectins with $\geq 1$ evolutionary conserved carbohydrate-recognition domain (CRD) (1). At present, 15 galectins have been identified in mammals, and are divided into three types based on domain organization as follows: i) Prototype galectins with one single CRD; ii) tandem-repeat galectins with two CRDs; iii) chimera-type galectins with a single CRD connected to a long, flexible N-terminal domain (1-3). Note that Galectin-3 is the only chimera-type galectin. Human galectin-3 is a $35-\mathrm{kDa}$ protein that is coded by a single gene, LGALS3, located on chromosome 14 . The N-terminal domain of galectin-3 is essential for its multimerization, sensitive to proteolysis by matrix metalloproteinases and may participate in the interaction with other intracellular proteins (3). Furthermore, the first 12 amino acids of galectin-3 are necessary for its secretion and nuclear translocation $(4,5)$. The $\mathrm{C}$-terminal CRD of galectin is responsible for its interaction with glycoconjugates containing $\mathrm{N}$-acetyllactosamine. Thus, galectin-3 binds proteins in a carbohydrate-dependent and -independent manner.

Galectin-3 is widely expressed in human tissues, including all types of immune cell (macrophages, monocytes, dendritic cells, eosinophils, mast cells, natural killer cells, and activated $\mathrm{T}$ and $\mathrm{B}$ cells), epithelial cells, endothelial cells and sensory 
neurons $(3,6)$. The expression of galectin-3 in tissues is developmentally regulated; it is more abundant during embryogenesis and development compared with adult life (7). Furthermore, during the early stages of embryogenesis, its expression pattern is more specific, located predominantly in the epithelia, kidney, chondrocytes and liver (8). However, galectin-3-knockout mice are viable without obvious abnormalities with the exception of premature senescence $(9,10)$.

Galectin-3 is predominantly located in the cytoplasm and shuttles into the nucleus (Fig. 1). In addition, it is secreted to the cell surface and into biological fluids (3). The different locations of galectin-3 contribute to its various functions. In the cytoplasm, galectin-3 is important for cell survival, due to its interaction with certain survival-associated proteins, including B-cell lymphoma-2 (Bcl-2) and activated guanosine-5'-triphosphate (GTP)-bound K-Ras. In the nucleus, galectin-3 promotes pre-mRNA splicing and regulates gene transcription, whereas extracellular galectin-3 modulates cell-cell interactions, including between epithelial cells and the extracellular matrix. Thus, it is involved in cell differentiation, inflammation, fibrogenesis and the host defense $(3,11)$ Therefore, galectin-3 is pivotal in numerous biological activities including cell growth, apoptosis, pre-mRNA splicing, differentiation, transformation, angiogenesis, inflammation, fibrosis and host defense. Previous evidence has indicated that galectin-3 is involved in the pathogenesis of cardiovascular remodeling, as well as in various autoimmune and inflammatory processes $(2,6,7,12-18)$.

A total of $97.5 \%$ of the galectin-3 reference population was $27.5 \mathrm{ng} / \mathrm{ml}$ according to the product insert of an ARCHITECT Galectin-3 assay (www.abbottdiagnostics.com). Both increased and decreased expression levels of galectin-3 are observed in various types of disease including heart, renal and liver disease, cancer and infections. Furthermore, galectin-3 is a stable biomarker and is not associated with age, body mass index or sex $(19,20)$. Furthermore, galectin-3 does not exhibit circadian variation and increases marginally following exercise, returning to normal levels after 1-3 $\mathrm{h}$ (21). Therefore, galectin-3 may be used in the diagnosis and prognosis of various types of disease, and therefore may also serve as a therapeutic target for treating disease. Despite several reviews commenting on these uses, numerous studies have been published in the last 3 years and provided certain novel ideas, particularly for the use of galectin-3 in humans. Thus, the present review summarizes the current literature, regarding biomarker characteristics and possible therapeutic applications of galectin-3 in disease.

\section{Galectin-3 and cardiovascular disease}

Elevated serum galectin-3 levels have been detected in almost all types of cardiovascular disease and its prognostic value for different clinical outcomes has been extensively investigated in patients (Table I).

Heart failure $(H F)$. Galectin-3 as a biomarker of fibrosis and inflammation has been implicated in the development and progression of HF, and may predict increased morbidity and mortality. Two recent meta-analyses demonstrated that increased expression levels of galectin-3 are associated with mortality in acute and chronic HF $(20,22)$, whereas another systematic review indicated that galectin-3 is ineffective for predicting all-cause mortality and cardiovascular mortality, particularly under the influence of certain clinical factors including estimated glomerular filtration rate (eGFR), left ventricular ejection fraction (LVEF) and N-terminal pro-B-type natriuretic peptide (NT-proBNP) (23).

A prospective cohort study with a 26 -month follow-up revealed that galectin-3 expression levels are independent predictors of 26-month mortality in patients with chronic $\mathrm{HF}$, and that a galectin-3 level $>21 \mathrm{ng} / \mathrm{ml}$ was associated with increased mortality (24). In HF patients with coronary heart disease, serum galectin-3 levels were increased, and were an independent predictor of all-cause mortality and re-hospitalization. Galectin-3 levels were markedly associated with outcomes in HF patients with a preserved ejection fraction (HFpEF) compared with HF patients with a reduced ejection fraction (HFrEF) (25). Galectin-3 is also associated with HF severity and exhibits dynamic changes during mechanical unloading, and predicts survival rates following the use of a left ventricular assist device (LVAD). Furthermore, galectin-3 is associated with the development of cardiac allograft vasculopathy post-heart transplantation (HT). Galectin-3 may also serve as a novel biomarker in patients with HF, during LVAD support, and following HT (26). Using patients hospitalized for HF pooled from three cohorts, Meijers et al (27) demonstrated that the plasma galectin-3 concentration is useful for the prediction of near-term re-hospitalization (27). In patients with $\mathrm{HF}$ and functional mitral regurgitation who underwent mitral valve repair, high pre-operative serum galecin-3 was independently associated with the absence of left ventricular (LV) reverse remodeling following mitral valve repair (28). Furthermore, the prognostic value of galectin in patients with $\mathrm{HF}$ is not affected by HF therapeutic strategies (29-31) or age (32). However, the prognostic value of galectin-3 in HF may differ among various ethnicities. Using a sub-study of the Atherosclerosis Risk in Communities observational cohort (1,375 white patients and 434 black patients) between 2004 and 2005, galectin-3 was identified to be independently associated with a composite of HF or mortality among white patients; however, not among black patients. Thus, galectin-3 may have limited prognostic utility for predicting HF and mortality in black patients (33).

Changes in galectin-3 over time may be a more sensitive and accurate prognostic biomarker for HF. Galectin-3 expression levels are elevated in a substantial proportion of patients with HF, particularly those with more severe HF and renal dysfunction (34). Galectin-3 expression levels increase over time in these patients and the increase is independently associated with a poorer clinical outcome (34). In the Valsartan Heart Failure Trial over a 4-month follow-up, for every $1 \mu \mathrm{g} / \mathrm{l}$ increase in galectin-3, there was an associated increased risk of mortality, primary morbid event and also hospitalization for $\operatorname{HF}(2.9,2.1$ and 2.2\%, respectively) (34). In the Controlled Rosuvastatin Multinational Trial in Heart Failure (over a 3-month follow-up) and in the Coordinating Study Evaluating Outcomes of Advising and Counseling Failure trial (over a 6-month follow-up), increased galectin-3 expression levels were observed $(<17.8$ to $>17.8 \mathrm{ng} / \mathrm{ml}$ ). This was associated with a significant increase in hospitalization and mortality 


$\begin{aligned} & \text { Cytoplasm } \\ & \text { cell survival (growth, } \\ & \text { cycle and apoptosis) }\end{aligned}$
Galectin-3
pre-mRNA splicing
transcription regulation

Figure 1. Functions of galection-3 in different locations including the cytoplasm, nucleus, cell surface and circulation.

due to $\mathrm{HF}$, with an increase of $>15 \%$ corresponding to a $50 \%$ increased in relative hazard of adverse events, despite following extensive clinical adjustments including age, sex, diabetes mellitus, LVEF, renal function, medication (e.g. $\beta$-blockers, angiotensin converting enzyme inhibitors and angiotensin receptor blockers) and NT-proBNP (35). In patients with LV systolic dysfunction with $>10$-month follow-up, an increase $<20 \mathrm{ng} / \mathrm{ml}$ was significantly associated with a lower rate of adverse cardiovascular events and independently predicted fewer adverse cardiovascular events following extensive clinical adjustments. However, HF therapeutic strategies including angiotensin-converting-enzyme inhibitors, angiotensin II receptor blockers and thiazide diuretic exhibited no clear effects on galectin-3 expression levels (29). In patients with stable chronic HF, the change in galectin-3 expression levels over time, including that at 6 months, are improved predictors of cardiovascular events compared with baseline galectin-3 levels (36). In contrast, Miller et al (37) identified that serial galectin-3 monitoring in ambulatory HF patients provided no additional prognostic benefit.

The association of galectin-3 with other cardiac function parameters remains controversial. A previous study demonstrated that in-patients with acute decompensated HF exhibited no significant association between serum galectin-3 expression levels and arterial stiffening markers, whereas increased galectin-3 expression levels were associated with impaired ventricular-arterial coupling, elevated pulmonary artery pressures and severe systolic dysfunction (38). Increased galectin-3 expression levels and arterial pulmonary pressure were identified to be independent risk factors for all-cause mortality and readmission (38). Galectin-3 expression levels demonstrated no difference between patients with HFpEF or HFrEF. However, it was associated with diastolic dysfunction severity and LV stiffness in patients with HFpEF, and associated with poor clinical outcome(s) independent of renal dysfunction and other risk factors in patients with HFpEF (39). Furthermore, for patients with compensated systolic HF undergoing treatment, galectin-3 demonstrated no association with eGFR, LVEF or functional capacity (40). The serum levels of galectin-3 are associated with changes in the LV structure and function, indicating that galectin-3 may be involved in the process of LV remodeling in chronic HF (41).

Galectin-3 reflects the inflammatory status and fibrosis, and may be useful for evaluating cardiac and renal function; as such, it may serve as a cardio-renal biomarker. In outpatients with HF, increased serum levels of galectin-3 reflected increased neurohumoral activity and reduced eGFR, however, not myocardial function (42). In another study enrolling a group of outpatients with chronic HF, galectin-3 serum levels were significantly and independently associated with microalbuminuria (43). However, Zhang et al (44) reported that for inpatients with $\mathrm{HF}$, galectin-3 only predicted mortality associated with renal function for patients with an eGFR $>60 \mathrm{ml} / \mathrm{min} / 1.73 \mathrm{~m}^{2}$. Furthermore, for patients with HFpEF, galectin-3 was associated with renal dysfunction severity, and was not independently associated with the severity of pathophysiological derangements (45). Another cohort study confirmed that galectin-3 was markedly associated with renal function in outpatients with HF (46). Collectively, these results indicate that the adjustment for renal function may be required when interpreting the significance of galectin-3 expression levels.

The prognostic value of galectin-3 has also been compared with that of other available biomarkers. The Penn Heart Failure study assessed an ambulatory HF cohort, which was comprised of patients with reduced, preserved or recovered LVEF. When this was compared with the established biomarkers for $\mathrm{HF}$ [including soluble suppression of tumorigenicity 2 (sST2), troponin I and B-type natriuretic peptide (BNP)], gelectin-3 and BNP were revealed to be the most accurate risk discriminators for patients with preserved and recovered LVEF through a 5 year follow-up, respectively (47). In patients with HFpEF, galectin-3 was a significantly more sensitive, but less specific as a biomarker when compared with BNP (48), whereas another study demonstrated the opposite conclusion, that the specificity of galectin-3 for predicting chronic HF was increased compared with that of N-terminal pro-BNP (NT-proBNP; however, its sensitivity was not comparatively increased (49). When patients with HF were stratified using eGFR values and the predictive value of fibroblast growth factor-23, galectin-3 and sST2 was compared, sST2 was the best predictor of mortality in patients with the lowest eGFR values, fibroblast growth factor-23 was the most relevant biomarker for patients with HF and intermediate eGFR values, and galectin-3 was the best biomarker for patients with $\mathrm{HF}$ and eGFR values $>73 \mathrm{ml} / \mathrm{min} / 1.73 \mathrm{~m}^{2}$ (50). However, galectin-3 has decreased prognostic value compared with matrix metalloproteinase-2 regarding clinical outcome prediction in patients with chronic systolic HF (51). In addition, galectin-3 has less prognostic value than sST2 for long-term risk stratification of ambulatory HF patients (52). One study speculated that SST2 may be more useful for monitoring long-term $\mathrm{HF}$ and that galectin-3 may be more useful for the diagnosis of HF remodeling (53).

The combination of galectin-3 with BNP provided an improved predictive value in discharged patients with $\mathrm{HF}$ following an acute decompensated HF episode compared to BNP alone (54). Galectin-3 alone as a risk predictor was not effective enough to assess sudden or in-hospital mortality, whereas combining galectin-3 and NT-proBNP levels significantly improved discrimination and reclassification when predicting all-cause and cardiovascular-associated mortality (55). The combination of galectin-3 and ST2 may be used to identify high systemic fibrosis in patients with acute $\mathrm{HF}$, thus providing a powerful risk stratification value (56). Therefore, galectin-3 is not recommended for use as a single prognostic biomarker for patients with HF; however, it is recommended in combination with other established biomarkers (23). 


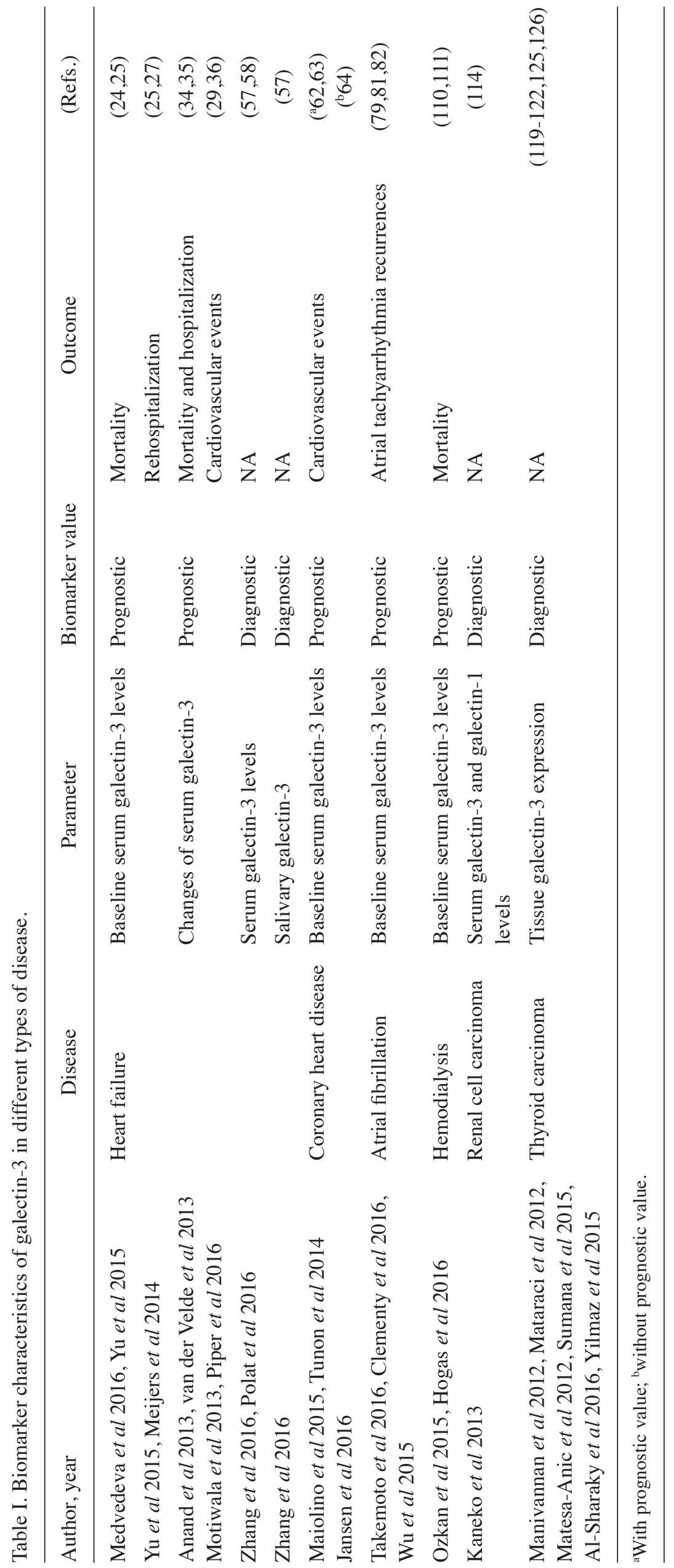


Galection-3 may also be used for the diagnosis of HF. In a previous study, the areas under the receiver operating characteristic curve for serum and salivary galectin-3 were 0.86 and 0.73 , respectively (57). In patients with $\mathrm{HFpEF}$, the area under the curve for serum galectin-3 was 0.98 (58). These results indicated the potential utility of using galectin- 3 to diagnose HF.

Coronary heart disease (CHD) and myocardial infarction $(M I)$. In patients with aortic valve stenosis, galectin-3 expression levels in serum and the myocardium were positively associated with levels of fibrosis and relative wall thickness, which are crucial indicators of geometric remodeling (59). Furthermore, galectin-3 in valvular interstitial cells obtained from patient's aortic stenosis induced the expression of inflammatory, fibrotic and osteogenic markers. In addition, its inhibitor, modified citrus pectin, decreased the expression levels of inflammatory, fibrotic and osteogenic markers in valvular interstitial cells undergoing osteoblastic differentiation, indicating its potential function in calcification in aortic stenosis (60). However, a prospective study which enrolled patients with at least mild degenerative aortic stenosis from two ongoing cohort studies demonstrated that galectin-3 was not associated with aortic stenosis severity or functional status, and did not provide prognostic information on the occurrence of aortic stenosis-associated events (61).

In a prospective cohort study with long-term follow-up (median, 7.2 years) in patients with CHD, galectin-3 presented as a strong independent predictor of cardiovascular mortality (62). In patients with chronic CHD, increased serum galectin-3 levels were associated with a greater incidence of cardiovascular events (63). In contrast, another large cohort study with a 13-year follow-up of patients with stable CHD, following adjustment for markers of hemodynamic stress, myocardial injury, inflammation and renal dysfunction, galectin-3 was not able to independently predict recurrent cardiovascular events (64). In patients with coronary artery disease, serum galectin-3 levels exhibited a significantly positive association with coronary artery disease severity, as determined by the Gensini score and number of diseased vessels (65), and increased serum levels of galectin-3 reflected the increased degree of myocardial fibrosis (66). Contrastingly, in patients with acute coronary syndrome, serum galectin-3 levels demonstrated a significantly positive association with the Gensini score; however, not with the number of diseased vessels (67). In addition, acute coronary syndrome patients with higher galectin-3 expression levels exhibited a decreased LVEF and eGFR (68).

In patients with a first anterior ST-elevated myocardial infarction (STEMI) and left anterior descending artery occlusion treated by primary percutaneous coronary intervention (pPCI), increased galectin-3 serum levels were measured during hospitalization and were associated with an increased risk of LV remodeling (69). Furthermore, elevated galectin-3 expression levels were associated with a higher rate of new-onset atrial fibrillation (AF) and diuretic treatment during hospitalization, and were the most effective independent predictor of the combined 30-day major adverse clinical outcome in patients with first MI without prior HF treated with pPCI $(70,71)$. Galectin-3 levels were also associated with reinfarction following initial MI (72). Galectin-3 measured acutely following STEMI was demonstrated as an independent predictor of increased extracellular volume during a 6-month follow-up, which may be useful for long-term risk stratification (73), and may be used to predict LVEF and infarction size after 4 months when measured immediately following a MI (74). In addition, serum galectin-3 levels varied significantly following a STEMI over a short time period and were associated with the timing of reperfusion (75). In acute MI, galectin-3 expression levels were positively and significantly associated with certain inflammatory factors (76), whereas another study demonstrated that galectin-3 expression levels did not change during acute MI and had no association between galectin-3 levels and acute ischemic myocardial injury (77). In acute MI, galectin-3 was positively and significantly associated with certain biomarkers including matrix metalloproteinase 3, monocyte chemoattractant protein-1, and interleukin (IL)-8 involved in extracellular matrix turnover, but not with LV remodeling (78). Furthermore, galectin-3 was positively associated with MI size and LV remodeling in patients with a history of complicated MI (77).

Other types of cardiac disease. Galectin-3 expression levels were increased in patients with AF, particularly in persistent AF $(79,80)$. Furthermore, galectin-3 expression independently predicted atrial tachyarrhythmia recurrences following a single ablation procedure $(79,81,82)$. In addition, galectin-3 was independently associated with new-onset AF (83), with atrial remodeling (84) and with left atrial volume index in AF patients with preserved LV function (80). However, the rhythm outcome of catheter ablation cannot be predicted using galectin-3 levels (85).

In patients with hypertension, galectin-3 was independently associated with LV remodeling and, therefore, may be a valuable biomarker for the detection of early cardiac remodeling in hypertension (86). In addition, it was associated with ambulatory microvolt $\mathrm{T}$-wave alternans positivity, decreased eGFR and increased LV myocardial index in hypertensive patients (87). Increased galectin-3 expression levels were observed in patients with pulmonary arterial hypertension (88). Increased galectin-3 was associated with multiple indices of right ventricle function and morphology (88), and was predictive of impaired right ventricle function (89).

In patients with hypertrophic cardiomyopathy, galectin-3 expression levels were increased and associated with the increased degree of LV hypertrophy; however, it was not associated with decreased myocardial LV diastolic and systolic functions (90). Furthermore, galectin-3 was associated with late gadolinium enhancement-assessed myocardial replacement fibrosis in patients with non-ischemic dilated cardiomyopathy (91).

Galectin-3 may serve as a biomarker for post-HT outcomes. Galectin-3 analyzed 10 days following HT displayed an association with heart function assessed 1 year after HT (92). Furthermore, galectin-3 fluctuated in patients followed up for 12 months after HT, and a novel process was indicated when galectin-3 increased by double or decreased by one-half compared to the baseline level (93). Contrastingly, Grupper et al (94) reported that although the galectin-3 expression level increased despite HT, and was associated with 
renal dysfunction, it was not associated with the presence of myocyte hypertrophy and interstitial fibrosis post HT (94).

Patients exhibiting peripheral artery disease also demonstrated increased galectin-3 levels, and galectin-3 was positively associated with homeostatic model assessment, but not arterial elasticity and microalbuminuria following adjustment for age and sex (95). A prospective observational study indicated that elevated plasma galectin-3 levels were markedly associated with inflammation, severity and poor prognosis following intracerebral hemorrhage (96). In adults with single-ventricle Fontan circulation, elevated galectin-3 was associated with an increased risk of non-elective cardiovascular hospitalization or mortality (97). Contrastingly, a low galectin-3 intra-plaque concentration appears to be associated with clinically and ultrasonically defined unstable human carotid plaques in patients with high-grade carotid stenosis (98).

An increased plasma galectin-3 level was associated with increased myocardial fibrosis in patients with aldosterone-producing adenoma (99). In addition, increased plasma levels of galectin-3 facilitate with predicting the occurrence of postoperative strokes among female patients who undergo carotid endarterectomy (100). Galectin-3 expression levels were also associated with the severity and a poor prognosis following aneurysmal subarachnoid hemorrhage (101). However, in the general population, galectin-3 did not predict incident cardiometabolic disease following adjustment for cardiometabolic risk factors (102).

\section{Galectin-3 and renal disease}

Renal failure and associated complications. In a rat model of ischemia/reperfusion and folic acid-induced acute renal failure (ARF), galectin-3 mRNA expression levels began to increase $2 \mathrm{~h}$ after injury, and the increased levels continued until 28 days after injury in ischemic ARF and 7 days after injury in toxic ARF. Furthermore, in ischemic ARF, the level of galectin-3 mRNA expression was significantly negatively associated with serum reciprocal creatinine levels at $48 \mathrm{~h}$ after injury. In addition, galectin-3 was initially localized in tubules and subsequently in macrophages during the stages of regeneration. These results indicated that galectin-3 may be important in acute tubular injury and the subsequent regeneration stage (103).

In addition to its role in ARF, galectin-3 functions in chronic kidney disease (CKD). It may be used in the diagnosis of CKD, prediction of clinical outcomes in patients with $\mathrm{CKD}$, and prediction of renal function in the general population. Patients with CKD demonstrated reduced eGFR and increased serum galectin-3 expression, and galectin-3 exhibited an area under the receiver operating characteristic curve of 0.89 , indicating its potential role in the diagnosis of CKD. Furthermore, six-year kidney survival rates of a low $(\leq 6 \mathrm{ng} / \mathrm{ml})$ and a high (>6 ng/ml) galectin-3 group were 47.3 and $22.8 \%$, respectively (104). In the Framingham Offspring Study with 2,450 participants who attended cycle 6 (1995-1998) and had follow-up data at cycle 8 (2005-2008), increased serum galectin-3 levels at baseline were associated with increased risk of rapid eGFR decline and incident CKD (despite adjustments for known clinical predictors of CKD); however, it was not associated with the risk of incident albuminuria (105).
These results indicated that galectin-3 predicts tubulointerstitial fibrosis, but not glomerular injury (105). However, in the Cardiovascular Health Study with a community-based multicenter cohort of 2,763 older adults with no history of $\mathrm{HF}$, increased serum galectin-3 levels were not associated with a $30 \%$ decline in eGFR or the development of incident eGFR following adjustments for potential confounders and other cardiac biomarkers (106).

The association between galectin-3, renal function and adverse outcomes was investigated in two large cohorts of patients over broad ranges of renal function from the German Diabetes Mellitus Dialysis (4D) study (1,168 dialysis patients with type 2 diabetes mellitus; 4-year follow-up) and the Ludwigshafen Risk and Cardiovascular Health study (2,579 patients with coronary angiograms; 10-year follow-up). Patients were divided into three groups according to their renal function (stratified by eGFR). Baseline serum galectin-3 levels increased with declined renal function and were independently associated with clinical endpoints of cardiovascular endpoints, infection and all-cause mortality in patients with impaired renal function; however, not in participants with normal kidney function (107).

In patients undergoing maintenance hemodialysis (HD), serum galectin-3 levels were correlated with early velocities/early diastolic mitral annular velocities ( $\left.E^{\prime}\right)$, left atrial volume index, and E'. Further analysis demonstrated that galectin-3 may be used in the diagnosis of LV diastolic function with a sensitivity and specificity of 67.6 and $84.6 \%$, respectively (108). Serum galectin-3 levels were also revealed to be associated with LV hypertrophy independent of left ventricle geometry in patients with HD, as well as in the general population (109). A multi-center, prospective, observational study identified that an increased galectin-3 level was a prognostic determinant of all-cause mortality and cardiac mortality in patients with HD (110). Another study confirmed this finding, and the authors identified that $>23.73 \mathrm{ng} / \mathrm{ml}$ gelectin- 3 was an independent predictor of mortality in patients with HD (111).

Serum galectin levels were reported to be a predictor of therapeutic response to renal denervation. In patients with resistant hypertension undergoing renal sympathetic denervation, baseline serum galectin levels were significantly increased in responders compared with non-responders, and no significant changes in galectin-3 levels were observed during the follow-up period. These results indicated that galectin-3 may assist in identifying patients suitable for renal denervation (112).

Renal cell carcinoma (RCC). Expression levels of galectin-3 were identified to be upregulated in serum and tumor tissues of patients with RCC (113-117). Males were significantly associated with increased mRNA expression levels of galectin-1 and -3 in clear cell RCC, indicating that galectins may be involved in the pathogenesis of the higher prevalence of RCC in men (115). A marked overexpression of galectin-3 was predominantly identified in renal tumors with oncocytic features, including oncocytomas and chromophobe RCC with positive immunohistochemical rates of 100 and $89 \%$, respectively, whereas significantly decreased expression levels of galecin-3 were observed in clear cell and papillary RCCs (113). Furthermore, the combined use of galectin-1 and -3 for RCC 
diagnosis demonstrated specificity and sensitivity of 98 and $47 \%$, respectively (114). These results indicated the potential role of galectin-3 in the diagnosis of different types of RCC (Table I).

\section{Galectin-3 and cancer}

Thyroid carcinoma. Differentiating malignant lesions from benign thyroid lesions is clinically challenging. Even the most accurate method, thyroid fine needle aspiration biopsy, has only $70-90 \%$ accuracy (118). Thus, as a pro-angiogenic marker, the value of galectin-3 in the diagnosis of thyroid carcinoma has been widely investigated (Table I). The latest meta-analysis indicated that galectin-3 may be a potentially useful immunomarker to distinguish between patients with papillary thyroid carcinoma (PTC) and patients without PTC. In addition, PTC patients with positive expression of galectin-3 were prone to lymph node metastasis (118). However, there are controversial results regarding other types of thyroid carcinoma.

Previous studies support the potential diagnostic value of galectin-3 for malignant lesions. Manivannan et al (119) demonstrated that galectin-3 expression levels in tumor tissues differentiate benign from malignant follicular neoplasms. Focal and diffuse positivity for galectin-3 was associated with malignant thyroid follicular neoplasms (119). Mataraci et al (120) also identified that the percentage and intensity of staining for galectin-3 were increased in malignant lesions, particularly in papillary carcinomas (120). Galectin expression levels were significantly increased in malignant thyroid neoplasms when compared with benign neoplasms. However, no significant differences were identified when comparing galectin-3 expression levels in PTC and other malignant lesions. Previous studies have demonstrated that there was no marked staining intensity for intracytoplasmatic or intranuclear expression of galectin-3 in benign thyroid neoplasms. Furthermore, there was a lack of weak intensity for intracytoplasmatic or intranuclear expression of galectin-3 in malignant neoplasms, therefore, diffuse and strong staining for galectin-3 differentiates malignant from benign thyroid neoplasms $(121,122)$. The increased expression levels of galectin-3 on Thin-Prep fine needle aspiration cytology were associated with hypertrophy and/or cellular hyperproliferation, pathophysiological situations that are common to adenomas and thyroid carcinomas (123). Overexpression of galectin-3 protein was observed in papillary thyroid carcinoma with lymph node metastases (124). A previous study compared glypican-3 (a member of the glypican family of heparan-sulfate proteoglycans bound to the plasma membrane) with galectin-3 and demonstrated that galectin-3 was more sensitive in diagnosing thyroid carcinoma; however, it was less specific in discriminating follicular-patterned neoplasm (125). Besides tissue expression, the preoperative serum galectin-3 level had diagnostic value, as it was significantly higher in the cancer patients than in the control subjects (126).

Galectin-3 is also used in combination with other biomarkers for a differential diagnosis of thyroid lesions. The most commonly combined biomarkers are Hector Battifora mesothelial epitope-1 (HBME-1) and cytokeratin-19 (127-130). Galectin-3 and HBME-1 may be used as single discriminators between follicular thyroid adenoma and carcinoma. Significant differences in galectin-3 and HBME-1 were identified between benign and malignant lesions, and also between the subgroups of benign and malignant lesions (127-130). Galectin-3 and HBME-1 have an excellent sensitivity and specificity for malignant thyroid lesions (100 and 89.1\%, respectively) (129). Despite core needle biopsies leading to the diagnosis of the majority of thyroid nodules, the accuracy is increased by also observing the galectin-3, cytokeratin-19 and HBME-1 panels, indicating their additional diagnostic value when combined with routine histology (127-130). It was also reported that galectin 3, cluster of differentiation (CD)44 and, to an extent, HBME-1, are useful immunocytochemical parameters with the potential to support the fine needle aspiration cytology diagnosis of PTC, particularly in situations where the differential diagnoses is complicated (131). The levels of parafibromin and galectin-3 expression were significantly increased among patients with parathyroid adenoma, atypical parathyroid adenomas and parathyroid carcinoma, whereas HBME-1 expression levels were not (132). The level of parafibromin expression was increased, whereas galectin-3 expression was decreased in arathyroid adenoma (132). Parafibromin expression, galectin-3 negativity, and a Ki-67 proliferation index $<1 \%$ were identified to be beneficial in the differential diagnosis of parathyroid tumors (132). Another study reported that the loss of parafibromin and overexpression of galectin-3 and $\mathrm{Ki}-67$ may assist in distinguishing parathyroid carcinoma from other types of parathyroid tumor (133). The combination of two or three of these markers may produce improved sensitivity and/or specificity for the diagnosis of parathyroid carcinoma (133). Galectin-3 and Bcl-2 exhibited a similar trend of downregulation from high levels in PTC to low levels in anaplastic thyroid carcinoma. During thyroid tumor progression from PTC to anaplastic thyroid carcinoma, downregulation of galectin-3 and $\mathrm{Bcl}-2$ (antiapoptotic molecules) and a stepwise increase in survivin (inhibitor of apoptosis) were observed (134).

Contrastingly, certain studies indicated that galectin-3 is not a potential diagnostic or prognostic biomarker (135-138). Studies demonstrated that galectin-3 expression levels in tumor tissues were not significantly associated with age, sex, extrathyroidal extension, lymph node metastasis, or total metastasis, age, completeness of resection, invasion or size score category and cannot be used for prognostic prediction (135). In thyroid tumors of uncertain malignant potential, sytokeratin-19, galectin-3, HBME-1, and CD56 stained negatively in the majority of cases $(90.3,83.9,87.1$ and $61 \%$, respectively), and no statistically significant differences were observed when compared with the immunoprofile of benign thyroid lesions (136). In another study assessing the efficacy of cytokeratin 19, thyroperoxidase, HBME-1 and galectin-3 in the evaluation of the aggressiveness of PTC, increased levels of cytokeratin 19 expression and negative thyroperoxidase expression indicated the total tumor diameter of PTC; however, the expression levels of cytokeratin 19, thyroperoxidase, HBME-1, and galectin-3 did not contribute to the identification of PTCs with other potentially aggressive behaviors (137). In papillary microcarcinoma, the level of galectin-3 expression exhibited no significant association with prognostic factors, including extrathyroidal extension and lymph node metastasis (138). 
Hepatocellular carcinoma (HCC). Galectin-3 promotes tumor progression in HCC. In mice bearing $\mathrm{HCC}$, the galectin-3 expression level in tumor tissue was significantly increased, while serum galectin-3 levels also demonstrated obvious changes (139). In an N-diethylnitrosamine-induced HCC mouse model, galectin-3 knockout mice developed a significantly smaller tumor burden with a less invasive phenotype compared with the wild-type animals. Galectin-3 was upregulated in the wild-type HCC tumor tissue; however, not in the surrounding parenchyma. In vitro studies demonstrated that the migration of hepatoma cells was significantly decreased and the reorganization of the actin cytoskeleton, RhoA GTPase activity and phosphorylation of myosin light chain 2 were decreased in the galectin-3 small interfering RNA-transfected cells. Furthermore, in vitro and in vivo evidence demonstrated that galectin-3 deficiency reduced hepatoma cell proliferation and increased apoptosis among these cells. These results indicated that galectin-3 promotes hepatoma cell motility and invasion via an autocrine signaling pathway (140). Serum galectin-3 levels were decreased in chronic hepatitis $\mathrm{B}$ or $\mathrm{C}$ patients when compared with patients with $\mathrm{HCC}$ and cirrhosis; however, there were no significant differences identified between patients with HCC and patients with cirrhosis (141). Another study confirmed that there was no difference in serum galectin-3 levels in HCC and cirrhotic patients (142). HCC patients with metastatic spread and poor prognosis suffering from portal vein invasion exhibited elevated serum galectin-3 levels (142). Expression levels of galectin-3 in HCC tissues were significantly increased and were associated with a poor prognosis. Furthermore, galectin-3 expression levels in tumor cells stimulated angiogenesis (143). Collectively, these results indicate that galectin-3 may be used for prognosis, but not for the diagnosis of patients with HCC.

Prostate cancer. At present, results regarding the serum levels and tissue expression of galectin-3 in patients with prostate cancer are controversial. In patients with metastatic prostate cancer, serum galectin-3 levels were uniformly higher compared with those in control subjects without cancer (144). Furthermore, serum galectin-3 levels were positively associated with prostate specific antigen in prostate cancer patients, particularly at early clinical time course (145). Galectin-3 expression levels in prostate tissue were increased in benign prostatic hyperplasia compared with normal tissue samples and markedly lower in adenocarcinoma (146). Galectin-3 demonstrated nuclear and cytoplasmic localization in benign, adjacent-benign and tumor tissues, with a decreasing gradient of galectin-3 expression levels observed in benign, adjacent-benign and tumor tissue samples (147).

Pancreatic carcinoma. Tissue expression and serum levels of galectin-3 were significantly higher in pancreatic carcinoma tissues or patients with pancreatic carcinoma when compared with the adjacent non-tumorous tissues or in benign pancreatic diseases and healthy individuals (148). Higher galectin-3 expression levels in tissues were associated with poor differentiation tissues (148). Serum galectin-3 was not associated with carcinoembryonic antigen and CA19-9; however, a combination of these three markers may increase the diagnostic sensitivity of pancreatic carcinoma diagnosis to $97.5 \%$ (148). Furthermore, galectin-3 was differentially expressed in different pancreatic carcinoma tissues (149). Furthermore, there was an increased expression in pancreatic ductal adenocarcinoma; however, not in pancreatic neuroendocrine neoplasms and gastrointestinal stromal tumors. Thus, galectin-3 may be used to help diagnose pancreatic ductal adenocarcinoma and rule out pancreatic neuroendocrine neoplasms and gastrointestinal stromal tumors (149).

Colorectal cancer. The serum level of galectin-3 was increased 11.3-fold in patients with colorectal cancer and markedly increased 31-fold in those with metastases (150). Simultaneous determination of serum galectin-3 and -4 levels demonstrated an increased specificity and sensitivity in distinguishing patients with colorectal cancer without metastases from those with liver metastases. Furthermore, increased serum galectin-3/-4 expression levels at the time of primary tumor removal in patients without clinically detectable metastases were associated with poorer survival rates over the next 10 years (151). Increased serum galectin-3 expression levels were observed in patients with colon cancer when compared in patients with rectal cancer (152). No association was identified between tissue galectin-3 expression levels and clinicopathological parameters of patients with colorectal cancer, whereas the level of tissue galectin-3 expression was positively associated with serum IL-17 and IL-23. Serum galectin-3 levels were significantly associated with IL-17, but not IL-23 in patients with colorectal cancer (153). Shimura et al (152) also confirmed the serum galectin-3 levels was associated with IL-17 production. Furthermore, it was also inversely associated with the production of IL-10 and IL-12 (152). These results indicated that galectin-3 may be a key factor in the regulation of tumor-associated inflammatory processes.

Breast cancer. Expression levels of galectin-3 protein were significantly greater in the breast tumor tissues compared with the paracancerous tissue, and galectin-3 was markedly expressed in triple-negative breast cancers when compared with other types of breast cancer $(154,155)$. Furthermore, the expression levels of galectin-3 were not identified as an independent prognostic factor for breast cancer, but were associated with chemotherapeutic resistance (154). In addition, the serum galectin-3 level was significantly increased in breast cancer patients compared with healthy control subjects (150). However, two previous studies demonstrated that low galectin-3 expression levels in breast cancer were significantly associated with increased tumor vascular invasion, and reduced disease-free survival and long-term overall survival $(156,157)$. Furthermore, in vitro breast cancer stem cell models demonstrated that galectin-3 knockdown led to epithelial-mesenchymal transition, increased sphere-formation ability, drug-resistance and increased aldefluor activity. In addition, in vivo orthotopic mouse models demonstrated that galectin-3-negative breast cancer stem cells were associated with enhanced tumorigenicity. These results indicated that loss of galectin-3 may be associated with epithelial-mesenchymal transition and cancer stemness-associated traits, and therefore, may predict poor response to chemotherapy and poor prognosis (157). 
Bladder cancer. The serum and tissue expression levels of galectin-3 were statistically increased in patients with bladder cancer compared with control and cystitis groups. Serum galectin-3 levels were increased in patients with transitional cell carcinoma compared with squamous cell carcinoma. Patients with high-grade transitional cell carcinoma had a significantly increased serum galectin level compared with those with low-grade tumors, as did those with muscle-invasive transitional cell carcinoma compared with papillary non-invasive tumors $(158,159)$. These results indicated that galectin-3 may be a potential diagnostic biomarker for bladder cancer.

Gastric cancer. Serum levels of galectin-3 in patients with gastric cancer were significantly increased compared with those in benign disease patients and healthy control subjects, and the serum galectin-3 level was associated with lymph node metastasis and distant metastasis (160). Tissue galectin-3 expression was reduced by 1.5 -fold in $50 \%$ of gastric tumors. The reduced galectin-3 expression level was associated with the presence of distant metastasis, and with a higher invasive phenotype in vitro (161). In contrast, it was previously reported that baseline serum galectin-3 levels exhibited no significant difference between patients with gastric cancer and healthy control subjects. Serum galectin-3 levels were not associated with the stage of disease or chemotherapy responsiveness (162). However, these studies confirmed that the galectin-3 expression level had no association with overall survival rates, and was not a reliable biomarker for determining prognosis in gastric adenocarcinoma $(160,162,163)$.

Lymphoma. Serum galectin-3 levels were significantly higher in patients with non-acute promyelocytic leukemia compared with the control group subjects. Patients with higher galectin-3 expression levels had lower complete remission rates and a significantly shorter overall survival. An increased galectin-3 expression level was an independent poor prognostic marker (164). Furthermore, serum galectin-3 levels in patients with non-Hodgkin's lymphoma were associated with cardiovascular events and were significantly increased in patients with cardiovascular events compared with patients without a cardiovascular event. Overall, increased serum galectin was associated with increased 12-month cumulative cardiovascular events (165)

Other types of cancer. High expression levels of galectin-3 in endometrial tumor tissues were independently associated with tumor depth and histological grade, and were associated with shorter survival rates (166). The serum and tissue expression levels of galectin-3 were significantly increased in patients with osteosarcoma compared with control subjects. Increased galectin-3 expression levels in serum or tumors was associated with the Enneking stage of cancer (167). Furthermore, an increased tumor expression level was associated with the occurrence of metastasis (167). In oral squamous cell carcinoma, serum and tissue expression levels of galectin-3 were significantly increased compared with those in control subjects. Patients with an increased tumor load exhibited an increased expression of galectin-3 compared with those with a decreased tumor load. Furthermore, exogenous galectin-1 treatment significantly increased survival, proliferation and angiogenesis in oral squamous cell carcinoma cell lines (168). Galectin-3 was expressed in prolactin and adrenocorticotropic hormone-producing pituitary adenomas tumors with high positivity (91.6 and $90.9 \%$, respectively), and an increased expression level was a strong predictive marker for recurrence/tumor progression (169). In the gallbladder, the positive expression rates of galectin-3 were increased in adenocarcinoma compared with peritumoral tissues, polyps and chronic cholecystitis. An increased expression level of galectin-3 was associated with decreased overall survival and was an independent prognostic marker in gallbladder adenocarcinoma (170). These results indicate that expression levels of galectin-3 and the Sambucus nigra agglutinin binding site may have important effects on the carcinogenesis, progression and biological behaviors of gallbladder cancer (170).

Results regarding abnormal expression levels of galectin-3 in cancer have been summarized in Table II. Collectively, these studies reveal that galectin-3 is expressed abnormally in many types of cancer, which indicates that galectin-3 is not a tumor-specific biomarker. Thus, galectin-3 will be effective when applied in combination with other specific biomarkers.

\section{Galectin-3 as a therapeutic target}

As galecin-3 has been demonstrated to perform numerous functions in the pathogenesis of diseases outlined previously, and may serve as a therapeutic target for these diseases, its potential clinical applications have been evaluated using cell and animal models (Table III). RN1, a polysaccharide that binds to galectin-3 and suppresses its expression, significantly inhibited growth of pancreatic ductal adenocarcinoma cells in vitro, in vivo and in patient-derived xenografts (171). Galectin-3 targeted N-(2-hydroxypropyl) methacrylamide copolymer-(G3-C12)-5-fluorouracil conjugates significantly improved the anti-tumor activity of fluorouracil in nude mice bearing PC-3, a prostate tumor xenograft (172). TFD100, a glycopeptide from cod binds galectin-3 with picomolar affinity and blocks galectin-3-mediated angiogenesis, tumor-endothelial cell interactions and metastasis of prostate cancer cells in mice (173). Galectin-3C, a truncated, dominant negative form of galectin-3, hypothesized to act by blocking endogenous galectin-3, significantly reduced the growth, motility, invasion, and angiogenic potential of cultured ovarian cancer cell lines and primary cells established from ovarian cancer patients (174). Modified citrus pectin, a galectin inhibitor, blocked aldosterone-induced cardiac and renal fibrosis, and improved cardio renal dysfunction in experimental hyperaldosteronism (175). In addition, modified citrus pectin prevented isoproterenol-induced LV dysfunction and fibrosis in mice with HF and cardiac-specific hyperaldosteronism, inhibited adipose tissue inflammation and decreased the differentiation degree of adipocytes in obese mice, as well as reducing plaque progression in an atherosclerosis mouse model (176-178). Furthermore, N-acetyllactosamine, a galectin-3 inhibitor, reduced proteinuria, improved renal function and decreased renal damage in mice with hypertensive nephropathy and HF (177). Galectin-3-antagonists and a selective galactose-coumarin-derived galectin-3 inhibitor attenuated bleomycin-induced pulmonary fibrosis in mouse models $(179,180)$. GR-MD-02, a complex carbohydrate-based 


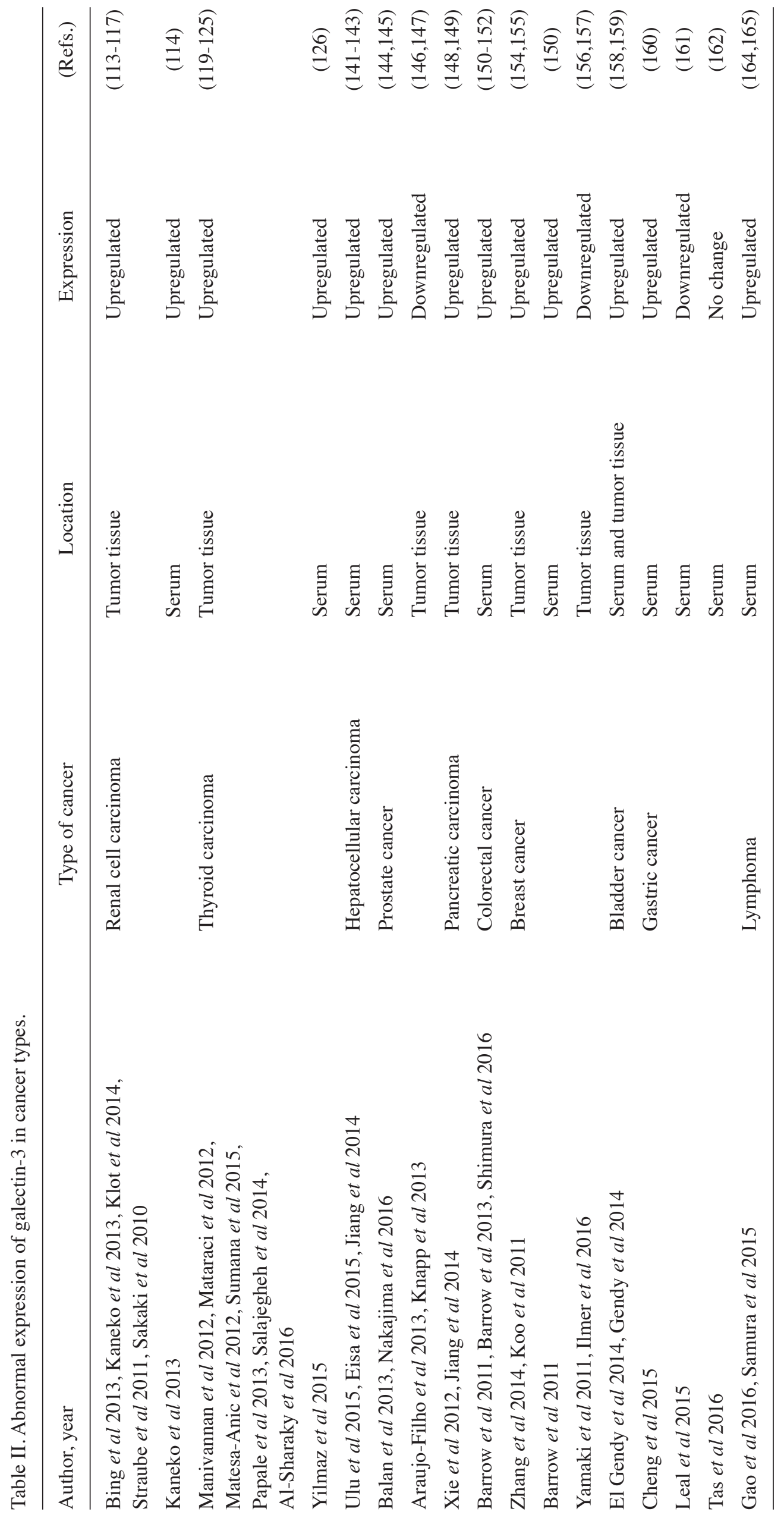




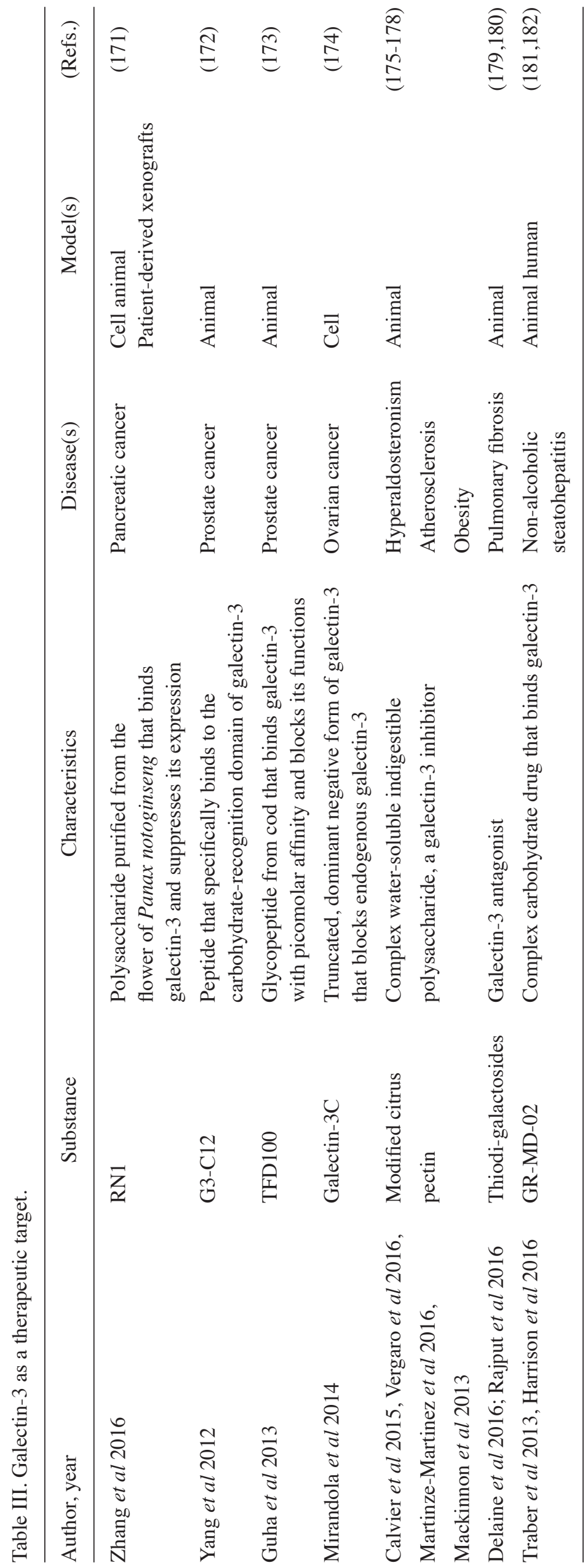


drug that binds to galectin-3, improved liver histology with significant reductions in non-alcoholic steatohepatitis (NASH) activity and collagen deposition, and reduced fibrosis in NASH mice with fibrosis (181). Furthermore, GR-MD-02 has been evaluated in a phase I clinical trial in participants with NASH and advanced fibrosis to determine its safety, pharmacokinetics and exploratory pharmacodynamic markers. GR-MD-02 doses were in the upper range $(8 \mathrm{mg} / \mathrm{kg})$ of the targeted therapeutic dose determined from pre-clinical data, and were safe and well tolerated with evidence of a pharmacodynamic effect, which therefore provided support for a phase II clinical trial (182).

\section{Conclusion}

Galectin-3 is a multifunctional protein involved in various types of disease. Its prognostic value in predicting the outcomes of $\mathrm{HF}$ and its diagnostic value in thyroid carcinoma diagnosis have been extensively investigated, and indicate its potential application for HF prognosis and thyroid carcinoma diagnosis (Table I). The development of detection methods of galectin-3 is required to improve the sensitivity, accuracy and consensus between different laboratories, and to provide supports for its clinical utility. In addition, normal reference ranges need to be established.

The functions of galectin-3 in fibrosis and immunity have also been extensively investigated, indicating its possible therapeutic utility in certain types of fibrotic disease and infection. In all cases, fibrotic disease progress to severe disease, including HF, renal failure and cirrhosis. Galectin-3 may represent a therapeutic approach to delay the progression of these diseases. Further animal studies and clinical trials are required to develop novel drugs targeting galectin-3.

\section{Acknowledgements}

The preset study was supported by the National Natural Science Foundation of China (grant nos. 81300517 and 81560668), Xizang Minzu University Fund (grant no. xzmyzp02) and the Shanghai Rising-Star Program (A type; grant no. 15QA1400800). Andrew Soh and Yijie Zheng are employees of Abbott Diagnostics. The other authors declare no conflicts of interest.

\section{References}

1. Argüeso P and Panjwani N: Focus on molecules: Galectin-3. Exp Eye Res 92: 2-3, 2011.

2. Saccon F, Gatto M, Ghirardello A, Iaccarino L, Punzi L and Doria A: Role of galectin-3 in autoimmune and non-autoimmune nephropathies. Autoimmun Rev 16: 34-47, 2017.

3. Newlaczyl AU and Yu LG: Galectin-3-a jack-of-all-trades in cancer. Cancer Lett 313: 123-128, 2011.

4. Gong HC, Honjo Y, Nangia-Makker P, Hogan V, Mazurak N, Bresalier RS and Raz A: The NH2 terminus of galectin-3 governs cellular compartmentalization and functions in cancer cells. Cancer Res 59: 6239-6245, 1999.

5. Menon RP and Hughes RC: Determinants in the N-terminal domains of galectin-3 for secretion by a novel pathway circumventing the endoplasmic reticulum-Golgi complex. Eur J Biochem 264: 569-576, 1999.

6. de Oliveira FL, Gatto M, Bassi N, Luisetto R, Ghirardello A, Punzi L and Doria A: Galectin-3 in autoimmunity and autoimmune diseases. Exp Biol Med (Maywood) 240: 1019-1028, 2015.

7. Pugliese G, Iacobini C, Ricci C, Blasetti Fantauzzi C and Menini S: Galectin-3 in diabetic patients. Clin Chem Lab Med 52: 1413-1423, 2014.
8. Dumic J, Dabelic S and Flögel M: Galectin-3: An open-ended story. Biochim Biophys Acta 1760: 616-635, 2006.

9. Colnot C, Fowlis D, Ripoche MA, Bouchaert I and Poirier F: Embryonic implantation in galectin 1/galectin 3 double mutant mice. Dev Dyn 211: 306-313, 1998.

10. Kim SJ, Lee HW, Gu Kang H, La SH, Choi IJ, Ro JY, Bresalier RS, Song J and Chun KH: Ablation of galectin-3 induces p27(KIP1)-dependent premature senescence without oncogenic stress. Cell Death Differ 21: 1769-1779, 2014.

11. Chen SC and Kuo PL: The role of galectin-3 in the kidneys. Int J Mol Sci 17: 565, 2016

12. Ruvolo PP: Galectin 3 as a guardian of the tumor microenvironment. Biochim Biophys Acta 1863: 427-437, 2016.

13. Meijers WC, Lopez-Andrés N and de Boer RA: Galectin-3, cardiac function, and fibrosis. Am J Pathol 186: 2232-2234, 2016.

14. Hu Y, Yéléhé-Okouma M, Ea HK, Jouzeau JY and Reboul P: Galectin-3: A key player in arthritis. Joint Bone Spine 84: 15-20, 2017.

15. Meijers WC, van der Velde AR, Pascual-Figal DA and de Boer RA: Galectin-3 and post-myocardial infarction cardiac remodeling. Eur J Pharmacol 763: 115-121, 2015.

16. Lala RI, Puschita M, Darabantiu D and Pilat L: Galectin-3 in heart failure pathology-'another brick in the wall'? Acta Cardiol 70: 323-331, 2015.

17. Funasaka T, Raz A and Nangia-Makker P: Galectin-3 in angiogenesis and metastasis. Glycobiology 24: 886-891, 2014.

18. Shin T: The pleiotropic effects of galectin-3 in neuroinflammation: A review. Acta Histochem 115: 407-411, 2013.

19. Meeusen JW, Johnson JN, Gray A, Wendt P, Jefferies JL, Jaffe AS, Donato LJ and Saenger AK: Soluble ST2 and galectin-3 in pediatric patients without heart failure. Clin Biochem 48: 1337-1340, 2015.

20. Schindler EI, Szymanski JJ, Hock KG, Geltman EM and Scott MG: Short- and long-term biologic variability of galectin-3 and other cardiac biomarkers in patients with Stable heart failure and healthy adults. Clin Chem 62: 360-366, 2016.

21. Issa SF, Christensen AF, Lottenburger T, Junker K, Lindegaard H, Hørslev-Petersen $\mathrm{K}$ and Junker P: Within-day variation and influence of physical exercise on circulating Galectin-3 in patients with rheumatoid arthritis and healthy individuals. Scand J Immunol 82: 70-75, 2015.

22. Chen A, Hou W, Zhang Y, Chen Y and He B: Prognostic value of serum galectin-3 in patients with heart failure: A meta-analysis. Int J Cardiol 182: 168-170, 2015.

23. Srivatsan V, George M and Shanmugam E: Utility of galectin-3 as a prognostic biomarker in heart failure: Where do we stand? Eur J Prev Cardiol 22: 1096-1110, 2015.

24. Medvedeva EA, Berezin II, Surkova EA, Yaranov DM and Shchukin YV: Galectin-3 in patients with chronic heart failure: Association with oxidative stress, inflammation, renal dysfunction and prognosis. Minerva Cardioangiol 64: 595-602, 2016.

25. Yu X, Sun Y, Zhao Y, Zhang W, Yang Z, Gao Y, Cai H, Li Y, Wang Q, Bian B and Nie J: Prognostic value of plasma galectin-3 levels in patients with coronary heart disease and chronic heart failure. Int Heart J 56: 314-318, 2015.

26. Coromilas E, Que-Xu EC, Moore D, Kato TS, Wu C, Ji R, Givens R, Jorde UP, Takayama H, Naka Y, et al: Dynamics and prognostic role of galectin-3 in patients with advanced heart failure, during left ventricular assist device support and following heart transplantation. BMC Cardiovasc Disord 16: 138, 2016.

27. Meijers WC, Januzzi JL, deFilippi C, Adourian AS, Shah SJ, van Veldhuisen DJ and de Boer RA: Elevated plasma galectin-3 is associated with near-term rehospitalization in heart failure: A pooled analysis of 3 clinical trials. Am Heart J 167: 853-860. e4, 2014.

28. Kortekaas KA, Hoogslag GE, de Boer RA, Dokter MM, Versteegh MI, Braun J, Marsan NA, Verwey HF, Delgado V, Schalij MJ and Klautz RJ: Galectin-3 and left ventricular reverse remodelling after surgical mitral valve repair. Eur J Heart Fail 15: 1011-1018, 2013.

29. Motiwala SR, Szymonifka J, Belcher A, Weiner RB, Baggish AL, Sluss P, Gaggin HK, Bhardwaj A and Januzzi JL: Serial measurement of galectin-3 in patients with chronic heart failure: Results from the ProBNP outpatient tailored chronic heart failure therapy (PROTECT) study. Eur J Heart Fail 15: 1157-1163, 2013.

30. Koukoui F, Desmoulin F, Galinier M, Barutaut M, Caubère C, Evaristi MF, Murat G, De Boer R, Berry M, Smih F and Rouet P: The prognostic value of plasma galectin-3 in chronic heart failure patients is maintained when treated with mineralocorticoid receptor antagonists. PLoS One 10: e0119160, 2015. 
31. Edelmann F, Holzendorf V, Wachter R, Nolte K, Schmidt AG, Kraigher-Krainer E, Duvinage A, Unkelbach I, Düngen HD, Tschöpe C, et al: Galectin-3 in patients with heart failure with preserved ejection fraction: Results from the Aldo-DHF trial. Eur J Heart Fail 17: 214-223, 2015.

32. Teixeira A, Arrigo M, Vergaro G, Cohen-Solal A and Mebazaa A: Clinical benefits of natriuretic peptides and galectin-3 are maintained in old dyspnoeic patients. Arch Gerontol Geriatr 68 : 33-38, 2017.

33. McEvoy JW, Chen Y, Halushka MK, Christenson E, Ballantyne CM, Blumenthal RS, Christenson RH and Selvin E: Galectin-3 and risk of heart failure and death in blacks and whites. J Am Heart Assoc 5: pii:e003079, 2016.

34. Anand IS, Rector TS, Kuskowski M, Adourian A, Muntendam P and Cohn JN: Baseline and serial measurements of galectin-3 in patients with heart failure: Relationship to prognosis and effect of treatment with valsartan in the Val-HeFT. Eur J Heart Fail 15: 511-518, 2013.

35. van der Velde AR, Gullestad L, Ueland T, Aukrust P, Guo Y, Adourian A, Muntendam P, van Veldhuisen DJ and de Boer RA Prognostic value of changes in galectin-3 levels over time in patients with heart failure: Data from CORONA and $\mathrm{COACH}$ Circ Heart Fail 6: 219-226, 2013.

36. Piper SE, de Courcey J, Sherwood RA, Amin-Youssef GF and McDonagh TA: Serial galectin-3 for the monitoring of optimally treated stable chronic heart failure: A pilot study. Int J Cardiol 207: 279-281, 2016.

37. Miller WL, Saenger AK, Grill DE, Slusser JP, Bayes-Genis A and Jaffe AS: Prognostic value of serial measurements of soluble suppression of tumorigenicity 2 and Galectin-3 in ambulatory patients with chronic heart failure. J Card Fail 22: 249-255, 2016.

38. Lala RI, Darabantiu D, Pilat L and Puschita M: Galectin-3: A link between myocardial and arterial stiffening in patients with acute decompensated heart failure? Arq Bras Cardiol 106: 121-129, 2016 (In English, Portuguese).

39. Beltrami M, Ruocco G, Dastidar AG, Franci B, Lucani B Aloia E, Nuti R and Palazzuoli A: Additional value of Galectin-3 to $\mathrm{BNP}$ in acute heart failure patients with preserved ejection fraction. Clin Chim Acta 457: 99-105, 2016.

40. Atabakhshian R, Kazerouni F, Raygan F, Amirrasouli H, Rahimipour A and Shakeri N: Assessment of the relationship between galectin-3 and ejection fraction and functional capacity in the patients with compensated systolic heart failure. Int Cardiovase Res J 8: 143-147, 2014.

41. Carrasco-Sánchez FJ, Aramburu-Bodas O, Salamanca-Bautista P, Morales-Rull JL, Galisteo-Almeda L, Páez-Rubio MI, Arias-Jiménez JL, Aguayo-Canela M and Pérez-Calvo JI: Predictive value of serum galectin-3 levels in patients with acute heart failure with preserved ejection fraction. Int J Cardiol 169: 177-182, 2013.

42. Stoltze Gaborit F, Bosselmann H, Kistorp C, Iversen K, Kumler T, Gustafsson F, Goetze JP, Sölétormos G, Tønder N and Schou M: Galectin 3: Association to neurohumoral activity, echocardiographic parameters and renal function in outpatients with heart failure. BMC Cardiovasc Disord 16: 117, 2016.

43. Iacoviello $\mathrm{M}$, Aspromonte $\mathrm{N}$, Leone $\mathrm{M}$, Paradies V, Antoncecchi V, Valle R, Caldarola P, Ciccone MM, Gesualdo L and Serio FD: Galectin-3 Serum levels are independently associated with microalbuminuria in chronic heart failure outpatients. Res Cardiovasc Med 5: e28952, 2015.

44. Zhang R, Zhang Y, An T, Guo X, Yin S, Wang Y, Januzzi JL Cappola TP and Zhang J: Prognostic value of sST2 and galectin-3 for death relative to renal function in patients hospitalized for heart failure. Biomark Med 9: 433-441, 2015.

45. AbouEzzeddine OF, Haines P, Stevens S, Nativi-Nicolau J, Felker GM, Borlaug BA, Chen HH, Tracy RP, Braunwald E and Redfield MM: Galectin-3 in heart failure with preserved ejection fraction. A RELAX trial substudy (Phosphodiesterase-5 inhibition to improve clinical status and exercise capacity in diastolic heart failure). JACC Heart Fail 3: 245-252, 2015

46. Zamora E, Lupón J, de Antonio M, Galán A, Domingo M, Urrutia A, Troya M and Bayes-Genis A: Renal function largely influences Galectin-3 prognostic value in heart failure. Int J Cardiol 177: 171-177, 2014.

47. French B, Wang L, Ky B, Brandimarto J, Basuray A, Fang JC, Sweitzer NK and Cappola TP: Prognostic value of galectin-3 for adverse outcomes in chronic heart failure. J Card Fail 22: 256-262, 2016

48. Yin QS, Shi B, Dong L and Bi L: Comparative study of galectin-3 and B-type natriuretic peptide as biomarkers for the diagnosis of heart failure. J Geriatr Cardiol 11: 79-82, 2014
49. Chen K, Jiang RJ, Wang CQ, Yin ZF, Fan YQ, Cao JT, Han ZH, Wang Y and Song DQ: Predictive value of plasma galectin-3 in patients with chronic heart failure. Eur Rev Med Pharmacol Sci 17: 1005-1011, 2013

50. Gruson D, Ferracin B, Ahn SA and Rousseau MF: Comparison of fibroblast growth factor 23, soluble ST2 and Galectin-3 for prognostication of cardiovascular death in heart failure patients. Int J Cardiol 189: 185-187, 2015.

51. Chang YY, Chen A, Wu XM, Hsu TP, Liu LY, Chen YH, Wu YW, Lin HJ, Hsu RB, Lee CM, et al: Comparison the prognostic value of galectin-3 and serum markers of cardiac extracellular matrix turnover in patients with chronic systolic heart failure. Int J Med Sci 11: 1098-1106, 2014.

52. Bayes-Genis A, de Antonio M, Vila J, Peñafiel J, Galán A, Barallat J, Zamora E, Urrutia A and Lupón J: Head-to-head comparison of 2 myocardial fibrosis biomarkers for long-term heart failure risk stratification: ST2 versus galectin-3. J Am Coll Cardiol 63: 158-166, 2014

53. Wu AH, Wians F and Jaffe A: Biological variation of galectin-3 and soluble ST2 for chronic heart failure: Implication on interpretation of test results. Am Heart J 165: 995-999, 2013.

54. Feola M, Testa M, Leto L, Cardone M, Sola M and Rosso GL: Role of galectin-3 and plasma B type-natriuretic peptide in predicting prognosis in discharged chronic heart failure patients. Medicine (Baltimore) 95: e4014, 2016.

55. Zhang Y, Zhang R, An T, Huang Y, Guo X, Yin S, Wang Y, Ji S, Lv R, Zhang J and Maisel A: The utility of galectin-3 for predicting cause-specific death in hospitalized patients with heart failure. J Card Fail 21: 51-59, 2015.

56. Wang CH, Yang NI, Liu MH, Hsu KH and Kuo LT: Estimating systemic fibrosis by combining galectin-3 and ST2 provides powerful risk stratification value for patients after acute decompensated heart failure. Cardiol J 23: 563-572, 2016.

57. Zhang X, Wan Y, Chata R, Brazzale A, Atherton JJ, Kostner K, Dimeski $G$ and Punyadeera C: A pilot study to demonstrate diagnostic potential of galectin-3 levels in saliva. J Clin Pathol 69: 1100-1104, 2016.

58. Polat V, Bozcali E, Uygun T, Opan S and Karakaya O: Diagnostic significance of serum galectin-3 levels in heart failure with preserved ejection fraction. Acta Cardiol 71: 191-197, 2016.

59. Zhou K, Zhou Y, Zhao Y, Tan C, Yuan Z, Li J, Liao X, Gu L and Zhou X: The relationship between Galectin-3 and different patterns of ventricular geometry remodelling in aortic valve stenosis. Heart Lung Circ 25: 371-377, 2016.

60. Sadaba JR, Martinez-Martinez E, Arrieta V, Álvarez V, Fernández-Celis A, Ibarrola J, Melero A, Rossignol P, Cachofeiro V and López-Andrés N: Role for Galectin-3 in calcific aortic valve stenosis. J Am Heart Assoc 5: e004360, 2016.

61. Arangalage D, Nguyen V, Robert T, Melissopoulou M, Mathieu T, Estellat C, Codogno I, Huart V, Duval X, Cimadevilla C, et al: Determinants and prognostic value of Galectin-3 in patients with aortic valve stenosis. Heart 102: 862-868, 2016.

62. Maiolino G, Rossitto G, Pedon L, Cesari M, Frigo AC, Azzolini M, Plebani M and Rossi GP: Galectin-3 predicts long-term cardiovascular death in high-risk patients with coronary artery disease. Arterioscler Thromb Vasc Biol 35: 725-732, 2015.

63. Tuñón J, Blanco-Colio L, Cristóbal C, Tarín N, Higueras J, Huelmos A, Alonso J, Egido J, Asensio D, Lorenzo O, et al: Usefulness of a combination of monocyte chemoattractant protein-1, galectin-3, and N-terminal probrain natriuretic peptide to predict cardiovascular events in patients with coronary artery disease. Am J Cardiol 113: 434-440, 2014

64. Jansen H, Koenig W, Jaensch A, Mons U, Breitling LP, Scharnagl H, Stojakovic T, Schunkert H, Brenner H and Rothenbacher D: Prognostic Utility of Galectin-3 for recurrent cardiovascular events during Long-term follow-up in patients with stable coronary heart disease: Results of the KAROLA study. Clin Chem 62: 1372-1379, 2016.

65. Aksan G, Gedikli Ö, Keskin K, Nar G, İnci S, Y1ldız SS, Kaplan Ö, Soylu K, Kilıçkesmez KO and Şahin M: Is galectin-3 a biomarker, a player-or both-in the presence of coronary atherosclerosis? J Investig Med 64: 764-770, 2016.

66. Lepojarvi ES, Piira OP, Pääkkö E, Lammentausta E, Risteli J, Miettinen JA, Perkiömäki JS, Huikuri HV and Junttila MJ: Serum PINP, PIIINP, galectin-3, and ST2 as surrogates of myocardial fibrosis and echocardiographic left venticular diastolic filling properties. Front Physiol 6: 200, 2015.

67. Gucuk Ipek E, Akin Suljevic S, Kafes H, Basyigit F, Karalok N, Guray Y, Dinc Asarcikli L, Acar B and Demirel H: Evaluation of galectin-3 levels in acute coronary syndrome. Ann Cardiol Angeiol (Paris) 65: 26-30, 2016. 
68. George M, Shanmugam E, Srivatsan V, Vasanth K, Ramraj B, Rajaram M, Jena A, Sridhar A, Chaudhury M and Kaliappan I: Value of pentraxin-3 and galectin-3 in acute coronary syndrome: A short-term prospective cohort study. Ther Adv Cardiovasc Dis 9: 275-284, 2015 .

69. Di Tano G, Caretta G, De Maria R, Parolini M, Bassi L, Testa S and Pirelli S: Galectin-3 predicts left ventricular remodelling after anterior-wall myocardial infarction treated by primary percutaneous coronary intervention. Heart 103: 71-77, 2017.

70. Szadkowska I, Wlazeł RN, Migała M, Szadkowski K, Zielińska M, Paradowski M and Pawlicki L: The association between galectin-3 and clinical parameters in patients with firs acute myocardial infarction treated with primary percutaneous coronary angioplasty. Cardiol J 20: 577-582, 2013.

71. Tsai TH, Sung PH, Chang LT, Sun CK, Yeh KH, Chung SY Chua S, Chen YL, Wu CJ, Chang HW, et al: Value and level of galectin-3 in acute myocardial infarction patients undergoing primary percutaneous coronary intervention. J Atheroscler Thromb 19: 1073-1082, 2012.

72. Szadkowska I, Wlazel RN, Migala M, Bajon-Laskowska K, Szadkowski K, Zielińska M, Paradowski M and Pawlicki L: The association between galectin-3 and occurrence of reinfarction early after first myocardial infarction treated invasively. Biomarkers 18: 655-659, 2013

73.Perea RJ, Morales-Ruiz M, Ortiz-Perez JT, Bosch X, Andreu D, Borras R, Acosta J, Penela D, Prat-González S, de Caralt TM, et al: Utility of galectin-3 in predicting post-infarct remodeling after acute myocardial infarction based on extracellular volume fraction mapping. Int J Cardiol 223 458-464, 2016

74. van der Velde AR, Lexis CP, Meijers WC, van der Horst IC, Lipsic E, Dokter MM, van Veldhuisen DJ, van der Harst P and de Boer RA: Galectin-3 and sST2 in prediction of left ventricular ejection fraction after myocardial infarction. Clin Chim Acta 452: 50-57, 2016

75. Milner TD, Viner AC, MacKinnon AC, Sethi T and Flapan AD Temporal expression of galectin-3 following myocardial infarction. Acta Cardiol 69: 595-602, 2014

76. Alturfan AA, Basar I, Emekli-Alturfan E, Ayan F, Koldas L and Emekli N: Galectin-3 and plasma cytokines in patients with acute myocardial infarction. Lab Med 45: 336-341, 2014.

77. Singsaas EG, Manhenke CA, Dickstein K and Orn S: Circulating Galectin-3 levels are increased in patients with ischemic heart disease, but are not influenced by acute myocardial infarction. Cardiology 134: 398-405, 2016.

78. Weir RA, Petrie CJ, Murphy CA, Clements S, Steedman T, Miller AM, McInnes IB, Squire IB, Ng LL, Dargie HJ and McMurray JJ: Galectin-3 and cardiac function in survivors of acute myocardial infarction. Circ Heart Fail 6: 492-498, 2013.

79. Takemoto Y, Ramirez RJ, Yokokawa M, Kaur K, Ponce-Balbuena D, Sinno MC, Willis BC, Ghanbari H, Ennis SR, Guerrero-Serna G, et al: Galectin-3 regulates atria fibrillation remodeling and predicts catheter ablation outcomes. JACC Basic Transl Sci 1: 143-154, 2016.

80. Gurses KM, Yalcin MU, Kocyigit D, Canpinar H, Evranos B, Yorgun H, Sahiner ML, Kaya EB, Ozer N, Tokgozoglu L, et al: Effects of persistent atrial fibrillation on serum galectin-3 levels Am J Cardiol 115: 647-651, 2015.

81. Clementy N, Benhenda N, Piver E, Pierre B, Bernard A Fauchier L, Pages JC and Babuty D: Serum galectin-3 levels predict recurrences after ablation of atrial fibrillation. Sci Rep 6: 34357,2016

82. Wu XY, Li SN, Wen SN, Nie JG, Deng WN, Bai R, Liu N, Tang RB, Zhang T, Du X, et al: Plasma galectin-3 predicts clinical outcomes after catheter ablation in persistent atrial fibrillation patients without structural heart disease. Europace 17: 1541-1547, 2015.

83. Chen D, Procter N, Goh V, Liu S, Chua SJ, Assadi-Khansari B, Stewart S, Horowitz JD, Sverdlov AL and Ngo DT: New onset atrial fibrillation is associated with elevated galectin-3 levels. Int J Cardiol 223: 48-49, 2016.

84. Yalcin MU, Gurses KM, Kocyigit D, Canpinar H, Canpolat U, Evranos B, Yorgun H, Sahiner ML, Kaya EB, Hazirolan T, et al: The association of serum galectin-3 levels with atrial electrical and structural remodeling. J Cardiovasc Electrophysiol 26 : 635-640, 2015.

85. Kornej J, Schmidl J, Ueberham L, John S, Daneschnejad S, Dinov B, Hindricks G, Adams V, Husser D and Bollmann A: Galectin-3 in patients with atrial fibrillation undergoing radiofrequency catheter ablation. PLoS One 10: e0123574, 2015.
86. Yao Y, Shen D, Chen R, Ying C, Wang C, Guo J and Zhang G: Galectin-3 predicts left ventricular remodeling of hypertension. J Clin Hypertens (Greenwich) 18: 506-511, 2016.

87. Pusuroglu H, Akgul O, Erturk M, Bolat I, Tasbulak O, Ornek V, Gul M, Ozyilmaz SO, Yildirim HA, Kokturk U, et al: Assessment of relationship between galectin-3 and ambulatory ECG-based microvolt T-wave alternans in sustained systolic-diastolic hypertension patients. Blood Press Monit 21: 265-270, 2016.

88. Calvier L, Legchenko E, Grimm L, Sallmon H, Hatch A, Plouffe BD, Schroeder C, Bauersachs J, Murthy SK and Hansmann G: Galectin-3 and aldosterone as potential tandem biomarkers in pulmonary arterial hypertension. Heart 102: 390-396, 2016

89. Agoston-Coldea L, Lupu S, Petrovai D, Mocan T and Mousseaux E: Correlations between echocardiographic parameters of right ventricular dysfunction and Galectin-3 in patients with chronic obstructive pulmonary disease and pulmonary hypertension. Med Ultrason 17: 487-495, 2015.

90. Yakar Tülüce S, Tülüce K, Cil Z, Emren SV, Akyildiz ZI and Ergene O: Galectin-3 levels in patients with hypertrophic cardiomyopathy and its relationship with left ventricular mass index and function. Anatol J Cardiol 16: 344-348, 2016.

91. Vergaro G, Del Franco A, Giannoni A, Prontera C, Ripoli A, Barison A, Masci PG, Aquaro GD, Cohen Solal A, Padeletti L, et al: Galectin-3 and myocardial fibrosis in nonischemic dilated cardiomyopathy. Int J Cardiol 184: 96-100, 2015.

92. Franeková J, Hošková L, Sečník P Jr, Pazderník M, Kotrbatá M, Kubíček Z and Jabor A: The role of timely measurement of galectin-3, NT-proBNP, cystatin C and hsTnT in predicting prognosis and heart function after heart transplantation. Clin Chem Lab Med 54: 339-344, 2016.

93. Franeková J, Kubíček Z, Hošková L, Kotrbatá M, Sečník P, Kautzner J and Jabor A: Long-term biological variability of galectin-3 after heart transplantation. Clin Chem Lab Med 53: $119-123,2015$

94.Grupper A, Nativi-Nicolau J, Maleszewski JJ, Geske JR, Kremers WK, Edwards BS, Kushwaha SS and Pereira NL: Circulating galectin-3 levels are persistently elevated after heart transplantation and are associated with renal dysfunction. JACC Heart Fail 4: 847-856, 2016.

95. Casanegra AI, Stoner JA, Tafur AJ, Pereira HA, Rathbun SW and Gardner AW: Differences in galectin-3, a biomarker of fibrosis, between participants with peripheral artery disease and participants with normal ankle-brachial index. Vasc Med 21: 437-444, 2016

96. Yan XJ, Yu GF, Jie YQ, Fan XF, Huang Q and Dai WM: Role of galectin-3 in plasma as a predictive biomarker of outcome after acute intracerebral hemorrhage. J Neurol Sci 368: 121-127, 2016.

97. Opotowsky AR, Baraona F, Owumi J, Loukas B, Singh MN Valente AM, Wu F, Cheng S, Veldtman G, Rimm EB and Landzberg MJ: Galectin-3 is elevated and associated with adverse outcomes in patients with single-ventricle fontan circulation. J Am Heart Assoc 5: e002706, 2016.

98. Kadoglou NP, Sfyroeras GS, Spathis A, Gkekas C, Gastounioti A, Mantas G, Nikita KS, Karakitsos P and Liapis CD: Galectin-3, carotid plaque vulnerability, and potential effects of statin therapy. Eur J Vasc Endovasc Surg 49: 4-9, 2015.

99. Liao CW, Lin YT, Wu XM, Chang YY, Hung CS, Wu VC, Wu KD and Lin YH; TAIPAI Study Group: The relation among aldosterone, galectin-3, and myocardial fibrosis: A prospective clinical pilot follow-up study. J Investig Med 64: 1109-1113, 2016.

100. Edsfeldt A, Bengtsson E, Asciutto G, Dunér P, Björkbacka H, Fredrikson GN, Nilsson J and Goncalves I: High plasma levels of Galectin-3 are associated with increased risk for stroke after carotid endarterectomy. Cerebrovasc Dis 41: 199-203, 2016.

101. Liu H, Liu Y, Zhao J, Liu H and He S: Prognostic value of plasma galectin-3 levels after aneurysmal subarachnoid hemorrhage. Brain Behav 6: e00543, 2016.

102. Nayor M, Wang N, Larson MG, Vasan RS, Levy D and Ho JE: Circulating Galectin-3 is associated with cardiometabolic disease in the community. J Am Heart Assoc 5: pii:e002347, 2015.

103. Nishiyama J, Kobayashi S, Ishida A, Nakabayashi I, Tajima O, Miura S, Katayama $\mathrm{M}$ and Nogami H: Up-regulation of galectin-3 in acute renal failure of the rat. Am J Pathol 157: 815-823, 2000.

104. Ji F, Zhang S, Jiang X, Xu Y, Chen Z, Fan Y and Wang W: Diagnostic and prognostic value of galectin-3, serum creatinine, and cystatin $\mathrm{C}$ in chronic kidney diseases. J Clin Lab Anal: Oct 11, 2017 (Epub ahead of print). doi: 10.1002/jcla.22074. 
105. O'Seaghdha CM, Hwang SJ, Ho JE, Vasan RS, Levy D and Fox CS: Elevated galectin-3 precedes the development of CKD. J Am Soc Nephrol 24: 1470-1477, 2013.

106. Bansal N, Katz R, Seliger S, DeFilippi C, Sarnak MJ, Delaney JA, Christenson R, de Boer IH, Kestenbaum B, Robinson-Cohen C, et al: Galectin-3 and Soluble ST2 and kidney function decline in older adults: The cardiovascular health study (CHS). Am J Kidney Dis 67: 994-996, 2016.

107. Drechsler C, Delgado G, Wanner C, Blouin K, Pilz S, Tomaschitz A, Kleber ME, Dressel A, Willmes C, Krane V, et al: Galectin-3, renal function, and clinical outcomes: Results from the LURIC and 4D studies. J Am Soc Nephrol 26: 2213-2221, 2015.

108. Gurel OM, Yilmaz H, Celik TH, Cakmak M, Namuslu M, Bilgiç AM, Bavbek N, Akcay A and Eryonucu B: Galectin-3 as a new biomarker of diastolic dysfunction in hemodialysis patients. Herz 40: 788-794, 2015.

109. Yilmaz H, Gurel OM, Celik HT, Bozkurt A, Yildirim ME, Bilgic I, Bilgic MA, Bavbek N and Akcay A: Relationship of galectin-3 to left ventricular geometry and hypertrophy in chronic hemodialysis patients. Herz 40: 702-708, 2015.

110. Ozkan G, Ulusoy S, Mentese A, Guvercin B, Karahan SC, Yavuz A, Altay DU and Ocal M: Can be galectin-3 a novel marker in determining mortality in hemodialysis patients? Clin Biochem 48: 768-773, 2015.

111. Hogas S, Schiller A, Voroneanu L, Constantinescu D, Timar R, Cianga P, Siriopol D, Bob F, Cianga C, Onofriescu M, et al: Predictive value for Galectin 3 and cardiotrophin 1 in hemodialysis patients. Angiology 67: 854-859, 2016.

112. Schwerg M, Eilers B, Wienecke A, Baumann G, Laule M, Knebel F, Stangl K and Stangl V: Galectin-3 and prediction of therapeutic response to renal sympathetic denervation. Clin Exp Hypertens 38: 399-403, 2016.

113. Bing Z, Lal P, Lu S, Ziober A and Tomaszewski JE: Role of carbonic anhydrase IX, $\alpha$-methylacyl coenzyme a racemase cytokeratin 7 , and galectin-3 in the evaluation of renal neoplasms: A tissue microarray immunohistochemical study. Ann Diagn Pathol 17: 58-62, 2013.

114. Kaneko N, Gotoh A,Okamura N,MatsuoE, TeraoS, Watanabe M, Yamada Y, Hamami G, Nakamura T, Ikekita M, et al: Potential tumor markers of renal cell carcinoma: $\alpha$-enolase for postoperative follow up, and galectin-1 and galectin-3 for primary detection. Int J Urol 20: 530-535, 2013.

115. von Klot CA, Kramer MW, Peters I, Hennenlotter J, Abbas M, Scherer R, Herrmann TR, Stenzl A, Kuczyk MA, Serth J and Merseburger AS: Galectin-1 and Galectin-3 mRNA expression in renal cell carcinoma. BMC Clin Pathol 14: 15, 2014.

116. Straube T, Elli AF, Greb C, Hegele A, Elsässer HP, Delacour D and Jacob R: Changes in the expression and subcellular distribution of galectin-3 in clear cell renal cell carcinoma. J Exp Clin Cancer Res 30: 89, 2011.

117. Sakaki M,Fukumori T,Fukawa T,ElsammanE, Shiirevnyamba A, Nakatsuji $\mathrm{H}$ and Kanayama HO: Clinical significance of Galectin-3 in clear cell renal cell carcinoma. J Med Invest 57: $152-157,2010$

118. Tang W, Huang C, Tang C, Xu J and Wang H: Galectin-3 may serve as a potential marker for diagnosis and prognosis in papillary thyroid carcinoma: A meta-analysis. Onco Targets Ther 9: 455-460, 2016.

119. Manivannan P, Siddaraju N, Jatiya L and Verma SK: Role of pro-angiogenic marker galectin-3 in follicular neoplasms of thyroid. Indian J Biochem Biophys 49: 392-394, 2012.

120. Mataraci EA, Ozgüven BY and Kabukcuoglu F: Expression of cytokeratin 19, HBME-1 and galectin-3 in neoplastic and nonneoplastic thyroid lesions. Pol J Pathol 63: 58-64, 2012.

121. Matesa-Anić D, Moslavac S, Matesa N, Cupić H and Kusić Z: Intensity and distribution of immunohistochemical expression of galectin-3 in thyroid neoplasms. Acta Clin Croat 51: 237-241, 2012.

122. Sumana BS, Shashidhar S and Shivarudrappa AS: Galectin-3 immunohistochemical expression in thyroid neoplasms. J Clin Diagn Res 9: EC07-EC11, 2015.

123. Papale F, Cafiero G, Grimaldi A, Marino G, Rosso F, Mian C, Barollo S, Pennelli G, Sorrenti S, De Antoni E and Barbarisi A: Galectin-3 expression in thyroid fine needle cytology (t-FNAC) uncertain cases: Validation of molecular markers and technology innovation. J Cell Physiol 228: 968-974, 2013.

124. Salajegheh A, Dolan-Evans E, Sullivan E, Irani S, Rahman MA, Vosgha H, Gopalan V, Smith RA and Lam AK: The expression profiles of the galectin gene family in primary and metastatic papillary thyroid carcinoma with particular emphasis on galectin-1 and galectin-3 expression. Exp Mol Pathol 96: 212-218, 2014.
125. Al-Sharaky DR and Younes SF: Sensitivity and specificity of Galectin-3 and Glypican-3 in Follicular-patterned and other thyroid neoplasms. J Clin Diagn Res 10: EC06-EC10, 2016.

126. Yilmaz E, Karsidag T, Tatar C and Tüzün S: Serum Galectin-3: Diagnostic value for papillary thyroid carcinoma. Ulus Cerrahi Derg 31: 192-196, 2015

127. Paunovic I, Isic T, Havelka M, Tatic S, Cvejic D and Savin S: Combined immunohistochemistry for thyroid peroxidase, galectin-3, CK19 and HBME-1 in differential diagnosis of thyroid tumors. APMIS 120: 368-379, 2012.

128. Abd-El Raouf SM and Ibrahim TR: Immunohistochemical expression of HBME-1 and galectin-3 in the differential diagnosis of follicular-derived thyroid nodules. Pathol Res Pract 210: 971-978, 2014

129. Trimboli P, Guidobaldi L, Amendola S, Nasrollah N, Romanelli F, Attanasio D, Ramacciato G, Saggiorato E, Valabrega $S$ and Crescenzi A: Galectin-3 and HBME-1 improve the accuracy of core biopsy in indeterminate thyroid nodules. Endocrine 52: 39-45, 2016.

130. Durry MF, Miskad UA, Leiwakabessy WN and Cangara MH: Diagnostic value of galectin-3 and hector battifora mesothelial epitope (hbme)-1 as a marker for malignancy in the diagnosis of thyroid lesions. Pathology 48 (Suppl 1): S122-S123, 2016.

131. Das DK, Al-Waheeb SK, George SS, Haji BI and Mallik MK: Contribution of immunocytochemical stainings for galectin-3, CD44, and HBME1 to fine-needle aspiration cytology diagnosis of papillary thyroid carcinoma. Diagn Cytopathol 42: 498-505, 2014.

132. Karaarslan S, Yurum FN, Kumbaraci BS, Pala EE, Sivrikoz ON, Akyildiz $\mathrm{M}$ and Bugdayci $\mathrm{MH}$ : The role of parafibromin, Galectin-3, HBME-1, and Ki-67 in the differential diagnosis of parathyroid tumors. Oman Med J 30: 421-427, 2015

133. Wang O, Wang CY, Shi J, Nie M, Xia WB, Li M, Jiang Y, Guan H, Meng XW and Xing XP: Expression of Ki-67, galectin-3, fragile histidine triad, and parafibromin in malignant and benign parathyroid tumors. Chin Med J (Engl) 125: 2895-2901, 2012

134. Selemetjev SA, Savin SB, Paunovic IR, Tatic SB and Cvejic D: Changes in the expression pattern of apoptotic molecules (galectin-3, Bcl-2, Bax, survivin) during progression of thyroid malignancy and their clinical significance. Wien Klin Wochenschr 127: 337-344, 2015.

135. Lee YM and Lee JB: Prognostic value of epidermal growth factor receptor, p53 and galectin-3 expression in papillary thyroid carcinoma. J Int Med Res 41: 825-834, 2013.

136. Nechifor-Boilă A, Cătană R, Loghin A, Radu TG and Borda A: Diagnostic value of HBME-1, CD56, Galectin-3 and Cytokeratin-19 in papillary thyroid carcinomas and thyroid tumors of uncertain malignant potential. Rom J Morphol Embryol 55: 49-56, 2014.

137. Liu Z, Li X, Shi L, Maimaiti Y, Chen T, Li Z, Wang S, Xiong Y, Guo H, He W, et al: Cytokeratin 19, thyroperoxidase, HBME-1 and galectin-3 in evaluation of aggressive behavior of papillary thyroid carcinoma. Int J Clin Exp Med 7: 2304-2308, 2014

138. Gweon HM, Kim JA, Youk JH, Hong SW, Lim BJ, Yoon SO, Park YM and Son EJ: Can galectin-3 be a useful marker for conventional papillary thyroid microcarcinoma? Diagn Cytopathol 44: 103-107, 2016.

139. Wang X, Yuegao, Bai L, Ibrahim MM, Ma W, Zhang J, Huang Y, Wang B, Song L and Tang J: Evaluation of annexin A7, Galectin-3 and Gelsolin as possible biomarkers of hepatocarcinoma lymphatic metastasis. Biomed Pharmacother 68: 259-265, 2014.

140. Serizawa N, Tian J, Fukada H, Baghy K, Scott F, Chen X, Kiss Z, Olson K, Hsu D, Liu FT, et al: Galectin 3 regulates HCC cell invasion by RhoA and MLCK activation. Lab Invest 95: 1145-1156, 2015.

141. Ulu M, Alacacioglu A, Yuksel E, Pamukk BO, Bozkaya G, Ari A, Yuksel A, Sop G and Alacacioglu I: Prognostic significance of serum galectin-3 levels in patients with hepatocellular cancer and chronic viral hepatitis. Saudi J Gastroenterol 21: 47-50, 2015

142. Eisa NH, Ebrahim MA, Ragab M, Eissa LA and El-Gayar AM: Galectin-3 and matrix metalloproteinase-9: Perspective in management of hepatocellular carcinoma. J Oncol Pharm Pract 21: 323-330, 2015.

143. Jiang SS, Weng DS, Wang QJ, Pan K, Zhang YJ, Li YQ, Li JJ, Zhao JJ, He J, Lv L, et al: Galectin-3 is associated with a poor prognosis in primary hepatocellular carcinoma. J Transl Med 12: 273, 2014.

144. Balan V, Wang Y, Nangia-Makker P, Kho D, Bajaj M, Smith D, Heilbrun L, Raz A and Heath E: Galectin-3: A possible complementary marker to the PSA blood test. Oncotarget 4: 542-549, 2013. 
145. Nakajima K, Heilbrun LK, Hogan V, Smith D, Heath E and Raz A: Positive associations between galectin-3 and PSA levels in prostate cancer patients: A prospective clinical study-I. Oncotarget 7: 82266-82272, 2016.

146. Araujo-Filho JL, Melo-Junior MR, Beltrão EI, de Lima LR, Antunes CB and de Carvalho LB Jr: Immunochemiluminescent detection of galectin-3 in tumoral tissue from prostate. Int J Clin Exp Pathol 6: 1861-1867, 2013.

147. Knapp JS, Lokeshwar SD, Vogel U,Hennenlotter J, SchwentnerC, Kramer MW, Stenzl A and Merseburger AS: Galectin-3 expression in prostate cancer and benign prostate tissues: Correlation with biochemical recurrence. World J Urol 31: 351-358, 2013.

148. Xie L, Ni WK, Chen XD, Xiao MB, Chen BY, He S, Lu CH, Li XY, Jiang F and Ni RZ: The expressions and clinical significances of tissue and serum galectin-3 in pancreatic carcinoma. J Cancer Res Clin Oncol 138: 1035-1043, 2012.

149. Jiang K, Lawson D, Cohen C and Siddiqui MT: Galectin-3 and PTEN expression in pancreatic ductal adenocarcinoma, pancreatic neuroendocrine neoplasms and gastrointestinal tumors on fine-needle aspiration cytology. Acta Cytol 58: 281-287, 2014.

150. Barrow H, Guo X, Wandall HH, Pedersen JW, Fu B, Zhao Q, Chen C, Rhodes JM and Yu LG: Serum galectin-2, -4 , and -8 are greatly increased in colon and breast cancer patients and promote cancer cell adhesion to blood vascular endothelium. Clin Cancer Res 17: 7035-7046, 2011.

151. Barrow H, Rhodes JM and Yu LG: Simultaneous determination of serum galectin-3 and -4 levels detects metastases in colorectal cancer patients. Cell Oncol (Dordr) 36: 9-13, 2013.

152. Shimura T, Shibata M, Gonda K, Nakajima T, Chida S, Noda M, Suzuki S, Nakamura I, Ohki S and Takenoshita S: Association between circulating galectin-3 levels and the immunological, inflammatory and nutritional parameters in patients with colorectal cancer. Biomed Rep 5: 203-207, 2016.

153. Petrovic S, Radosavljevic GD, Pantic J, Jovanovic I, Jankovic N and Arsenijevic N: Circulating and tissue galectin-1 and galectin-3 in colorectal carcinoma: Association with clinicopathological parameters, serum CEA, IL-17 and IL23. J BUON 21: 941-949, 2016.

154. Zhang H, Luo M, Liang X, Wang D, Gu X, Duan C, Gu H, Chen G, Zhao X, Zhao Z and Liu C: Galectin-3 as a marker and potential therapeutic target in breast cancer. PLoS One 9: e103482, 2014.

155. Koo JS and Jung W: Clinicopathlogic and immunohistochemical characteristics of triple negative invasive lobular carcinoma Yonsei Med J 52: 89-97, 2011.

156. Yamaki S, Fujii T, Yajima R, Hirakata T, Yamaguchi S, Fujisawa T, Tsutsumi S, Asao T, Yanagita Y, Iijima M and Kuwano H: Clinicopathological significance of decreased galectin-3 expression and the long-term prognosis in patients with breast cancer. Surg Today 43: 901-905, 2013

157. Ilmer M, Mazurek N, Gilcrease MZ, Byrd JC, Woodward WA, Buchholz TA, Acklin K, Ramirez K, Hafley M, Alt E, et al: Low expression of galectin-3 is associated with poor survival in node-positive breast cancers and mesenchymal phenotype in breast cancer stem cells. Breast Cancer Res 18: 97,2016.

158. El Gendy H, Madkour B, Abdelaty S, Essawy F, Khattab D, Hammam O, El Kholy A and Nour HH: Galectin 3 for the diagnosis of bladder cancer. Arab J Urol 12: 178-181, 2014.

159. Gendy HE, Madkour B, Abdelaty S, Essawy F, Khattab D, Hammam O and Nour HH: Diagnostic and prognostic significance of serum and tissue Galectin 3 expression in patients with carcinoma of the bladder. Curr Urol 7: 185-190, 2014.

160. Cheng D, Liang B and Li Y: Serum galectin-3 as a potential marker for gastric cancer. Med Sci Monit 21: 755-760, 2015.

161. Leal MF, Calcagno DQ, Chung J, de Freitas VM, Demachki S, Assumpção PP, Chammas R, Burbano RR and Smith MC: Deregulated expression of annexin-A2 and galectin-3 is associated with metastasis in gastric cancer patients. Clin Exp Med 15 415-420, 2015.

162. Tas F, Bilgin E, Tastekin D, Erturk K and Duranyildiz D: Clinical significance of serum Galectin-3 levels in gastric cancer patients. J Gastrointest Cancer 47: 182-186, 2016.

163. Gomes TS, Oshima CT, Forones NM, De Oliveira Lima F and Ribeiro DA: Expression of galectin-3 in gastric adenocarcinoma. Indian J Med Res 140: 69-76, 2014.

164. Gao N, Yu WZ, Guo NJ, Wang XX and Sun JR: Clinical significance of galectin-3 in patients with adult acute myeloid leukemia: A retrospective cohort study with long-term follow-up and formulation of risk scoring system. Leuk Lymphoma 58: 1394-1402, 2017.
165. Samura B: Galectin-3 as a prognostic biomarker in patients with Non-Hodgkin lymphoma. Georgian Med News: 7-11, 2015.

166. Lambropoulou M, Deftereou TE, Kynigopoulos S, Patsias A, Anagnostopoulos C, Alexiadis G, Kotini A, Tsaroucha A, Nikolaidou C, Kiziridou A, et al: Co-expression of galectin-3 and CRIP-1 in endometrial cancer: Prognostic value and patient survival. Med Oncol 33: 8, 2016

167. Zhou X, Jing J, Peng J, Mao W, Zheng Y, Wang D, Wang X, Liu $Z$ and Zhang $X$ : Expression and clinical significance of galectin-3 in osteosarcoma. Gene 546: 403-407, 2014.

168. Aggarwal S, Sharma SC and Das SN: Galectin-1 and galectin-3: Plausible tumour markers for oral squamous cell carcinoma and suitable targets for screening high-risk population. Clin Chim Acta 442: 13-21, 2015.

169. Righi A, Morandi L, Leonardi E, Farnedi A, Marucci G, Sisto A, Frank G, Faustini-Fustini M, Zoli M, Mazzatenta D, et al: Galectin-3 expression in pituitary adenomas as a marker of aggressive behavior. Hum Pathol 44: 2400-2409, 2013.

170. Yang LP, Jiang S, Liu JQ, Miao XY and Yang ZL: Up-regulation of galectin-3 and Sambucus nigra agglutinin binding site is associated with invasion, metastasis and poor-progression of the gallbladder adenocarcinoma. Hepatogastroenterology 59: 2089-2094, 2012

171. Zhang L, Wang P, Qin Y, Cong Q, Shao C, Du Z, Ni X, Li P and Ding K: RN1, a novel galectin-3 inhibitor, inhibits pancreatic cancer cell growth in vitro and in vivo via blocking galectin-3 associated signaling pathways. Oncogene 36: 1297-1308, 2017.

172. Yang Y, Zhou Z, He S, Fan T, Jin Y, Zhu X, Chen C, Zhang ZR and Huang Y: Treatment of prostate carcinoma with (galectin-3)-targeted HPMA copolymer-(G3-C12)-5-Fluorouracil conjugates. Biomaterials 33: 2260-2271, 2012

173. Guha P, Kaptan E, Bandyopadhyaya G, Kaczanowska S, Davila E, Thompson K, Martin SS, Kalvakolanu DV, Vasta GR and Ahmed $\mathrm{H}$ : Cod glycopeptide with picomolar affinity to galectin-3 suppresses T-cell apoptosis and prostate cancer metastasis. Proc Natl Acad Sci USA 110: 5052-5057, 2013.

174. Mirandola L, Yu Y, Cannon MJ, Jenkins MR, Rahman RL, Nguyen DD, Grizzi F, Cobos E, Figueroa JA and Chiriva-Internati M: Galectin-3 inhibition suppresses drug resistance, motility, invasion and angiogenic potential in ovarian cancer. Gynecol Oncol 135: 573-579, 2014.

175. Calvier L, Martinez-Martinez E, Miana M, Cachofeiro V, Rousseau E, Sádaba JR,ZannadF, Rossignol P and López-Andrés N: The impact of galectin-3 inhibition on aldosterone-induced cardiac and renal injuries. JACC Heart Fail 3: 59-67, 2015.

176. Vergaro G, Prud'homme M, Fazal L, Merval R, Passino C, Emdin M, Samuel JL, Cohen Solal A and Delcayre C: Inhibition of Galectin-3 pathway prevents isoproterenol-induced left ventricular dysfunction and fibrosis in mice. Hypertension 67: 606-612, 2016

177. Martinez-Martinez E, Calvier L, Rossignol P, Rousseau E, Fernández-Celis A, Jurado-López R, Laville M, Cachofeiro V and López-Andrés N: Galectin-3 inhibition prevents adipose tissue remodelling in obesity. Int J Obes (Lond) 40: 1034-1038, 2016.

178. MacKinnon AC, Liu X, Hadoke PW, Miller MR, Newby DE and Sethi T: Inhibition of galectin-3 reduces atherosclerosis in apolipoprotein E-deficient mice. Glycobiology 23: 654-663, 2013.

179. Delaine T, Collins P, MacKinnon A, Sharma G, Stegmayr J, Rajput VK, Mandal S, Cumpstey I, Larumbe A, Salameh BA, et al: Galectin-3-binding glycomimetics that strongly reduce bleomycin-induced lung fibrosis and modulate intracellular glycan recognition. Chembiochem 17: 1759-1770, 2016.

180. Rajput VK, MacKinnon A, Mandal S, Collins P, Blanchard H, Leffler H, Sethi T, Schambye H, Mukhopadhyay B and Nilsson UJ: A Selective Galactose-coumarin-derived Galectin-3 inhibitor demonstrates involvement of Galectin-3-glycan interactions in a pulmonary fibrosis model. J Med Chem 59: 8141-8147, 2016.

181. Traber PG and Zomer E: Therapy of experimental NASH and fibrosis with galectin inhibitors. PLoS One 8: e83481, 2013.

182. Harrison SA, Marri SR, Chalasani N, Kohli R, Aronstein W, Thompson GA, Irish W, Miles MV, Xanthakos SA, Lawitz E, et al: Randomised clinical study: GR-MD-02, a galectin-3 inhibitor, vs. placebo in patients having non-alcoholic steatohepatitis with advanced fibrosis. Aliment Pharmacol Ther 44: 1183-1198, 2016.

This work is licensed under a Creative Commons Attribution-NonCommercial-NoDerivatives 4.0 International (CC BY-NC-ND 4.0) License. 